\title{
Temporal and spatial variation of richness and abundance of the community of birds in the Pantanal wetlands of Nhecolândia (Mato Grosso do Sul, Brazil)
}

\author{
Reginaldo José Donatelli ${ }^{1}$, Donald P. Eaton ${ }^{2,3}$, Guilherme Sementili-Cardoso ${ }^{1,4}$, \\ Renata Marques Vianna ${ }^{1,4}$, Raphael Whitacker Gerotti ${ }^{1,4}$, Fernanda Gonçalves Rodrigues ${ }^{1,4}$ \\ \& Rafael Martos Martins ${ }^{1,4}$
}

1. Laboratório de Ornitologia. Universidade Estadual Paulista "Júlio de Mesquita Filho", Faculdade de Ciências, Departamento de Ciências Biológicas, campus de Bauru, São Paulo, Brasil, Cep 17033-360; rjdonat@yahoo.com.br

2. Ecology, Evolution and, Conservation Biology Program, University of Nevada, Reno, 1664 N. Virginia St., Reno, Nevada 89557-0208, USA.

3. Wildlife Conservation Society-Brazil, Rua Spipe Calarge, 2355, Vila Morumbi, Campo Grande, Mato Grosso do Sul 79052-070, Brazil; don.sada@dri.edu, deaton@wcs.org.

4. Programa de Pós-Graduação em Ciências Biológicas (Zoologia), Universidade Estadual Paulista "Júlio de Mesquita Filho", Instituto de Biociências, campus de Botucatu, São Paulo, Brasil, Cep 18680-000; guisemcar@yahoo.com.br, vianna_29@hotmail.com, raphael.whitacker@ibb.unesp.br, fefe.2909@hotmail.com, rafael.martos@yahoo.com.br

\section{Received 16-I-2017. Corrected 03-VII-2017. Accepted 03-VIII-2017.}

\begin{abstract}
The Pantanal wetlands represent one of the largest flood plains in the World, with extreme climatic variations between dry and wet seasons. The area shelters a high diversity of habitats, representing the main formations found in this sub-region: grasslands, savannah, forested savannah, riparian forests, bays and salines, and Negro river itself. This habitat variability determines the structure and dynamics of the bird community, because most species are closely related to specific habitats. For this, we studied the abundance of bird species from 2001 to 2004 in a Pantanal area of Fazenda Rio Negro, Aquidauana, Brazil. The abundance was compared among those four consecutive years, seasons (dry and wet), time of the day (morning and afternoon), and also between seven different habitats, in order to determine the variation in distribution patterns and habitats used by birds. For this, we used the linear transect method in each of the seven habitats, and recorded bird abundances to obtain richness. The richness registered in the mosaic of habitats was of 201 species for the savannah, 87 in forested savannah, 116 in the riparian forest, 75 in grasslands, 120 in bays, 92 in the salines and 64 in the Negro river, accounting for 348 species in the Pantanal of Rio Negro. Overall, 98 species of migratory birds were registered. The results highlighted some important issues regarding the total abundance of birds in Nhecolândia: Psittacidae was the most abundant family in the region, with prominence in all environments. Recurvirostridae, a monospecific family, showed expressive abundance due to the dominance of Himantopus mexicanus in the salinas, followed by Ardeidae, Anatidae and Cracidae. Other families with high abundance were Tyrannidae, Columbidae, Thraupidae and Emberizidae, all in predominantly terrestrial environments. Moreover: a) The highest number of specimens was recorded in the morning period and in the dry season, regardless of the habitat; b) there were no differences in abundance in the same habitat along the years, but the abundance was different among habitats. In general, the results indicated that there is a relatively stable bird population in each habitat along the annual cycle, but there were differences in abundance among habitats. Thus, additional studies on food availability in dry and wet seasons should be better explored in the future, either in this region or in other Pantanal regions. This fact could better explain the seasonal dynamics of the richness and abundance of birds in the Pantanal area in general. Rev. Biol. Trop. 65 (4): 1358-1380. Epub 2017 December 01.
\end{abstract}

Key words: pantanal, bird community, mosaic of habitats, Mato Grosso do Sul. 
The Pantanal wetlands stand out for being one of the largest flood plain in the world, in which extreme climatic variations occur between dry (April to September) and wet seasons (October to March). During the wet season, large areas are flooded (Por, 1995). In the sub-region of Nhecolândia, the terrain, together with the rainfall conditions, is considered a predominant factor, for the formation of permanent or temporary lagoons in low terrains, with transition to grassy formations, fields, savannahs and forest formations in higher numbers when compared to other sub-regions of the Pantanal (Alho, Lacher Jr, \& Gonçalves, 1988; Ratter, Pott, Pott, Cunha, \& Haridasan, 1988; Rodela, 2006).

The Pantanal is a complex of phyto-physiognomies that comprises numerous types of terrestrial and aquatic formations with the most diverse characteristics. In the terrestrial habitat, seasonal deciduous or semi-deciduous forests (including forest islands known as "capão" and riparian forests), fields of "murundus" (circular or elliptical micro topographies present on drainage slopes and headwaters, that remain temporarily or permanently flooded by rainwater; they are small usually round mounds, that often present with soil and vegetation different from the surrounding level area; Resende, Araújo, Oliveira, Oliveira, \& Ávila, 2004) and savannah formations with several levels of arboreal, shrub and graminoid coverings (including flooded monodominant formations) (Pott \& Silva, 2015). In the aquatic habitat, rivers, fresh or salty water (salines) of different sizes and limnological conditions, permanent flooded fields, as well as the vast intermittent drainage meshwork - meanders, low levels, oxbow lakes, and "corixos" (seasonal streams) - which act as expansion and contraction shafts of the water during the flood periods (Pott \& Silva, 2015). Amongst these characteristics, the number of lagoons and lakes is quite peculiar to this complex, numbering in the tens of thousands along its extension (Por, 1995). In the South-Central region of the Pantanal wetlands, two sub-sections marked by the great occurrence of fresh water (bays) and salty (saline) lagoons stand out: Paiaguás, at the North of the Taquari River, and Nhecolândia, at the South of the same river (Tomás, de Salis, Catella, Santos, \& Nunes., 2007).

Although the Pantanal occupies a significant area of South America, there are few avifauna studies throughout its region, perhaps due to transport difficulty during flood periods. Naumburg (1930), Mitchel (1957), Brown (1986), Cintra and Yamashita (1990), Dubs (1992), Tubelis and Tomas (2003), Nunes and Tomas (2004a and 2004b), Nunes, Tizianel \& Tomas (2006), Nunes, Silva \& Tomas (2008), Figueira, Cintra, Viana \& Yamashita (2006) and Donatelli, Posso \& Toledo (2014) are among the researchers who investigated the richness of the birds in several regions of Pantanal. Nevertheless, an analysis of the diversity and dynamics of bird species in the Pantanal region is still lacking.

Aiming to broaden the knowledge of the bird community of the Southern region of Pantanal, this work registered the abundance of birds in a mosaic of habitats in the Pantanal of the Rio Negro. It is a pristine area where there is no cattle rising, unlike the other farms in the region; moreover, there is little human influence, and it has become a relevant model area and a unique reference for research. Thus, data from annual, seasonal, time of day, and habitat variation of abundance of the community of birds were collected in order to determine whether there is any variation in the patterns of distribution and use of habitats by birds in the Fazenda Rio Negro, Pantanal de Rio Negro, Nhecolândia, Aquidauana, Mato Grosso do Sul, Brazil.

\section{MATERIAL AND METHODS}

Area of study: The study was developed in the Pantanal of Nhecolândia (Fig. 1A and Fig. 1B), in the Fazenda Rio Negro, city of Aquidauana, MS (19³0'00" S \& 56 $\left.6^{\circ} 12^{\prime} 30^{\prime} " \mathrm{~W}\right)$. The Pantanal of Nhecolândia is a region with lands higher than the surroundings areas, characterized by moderated, localized and of short duration floods, where the bays and salines 

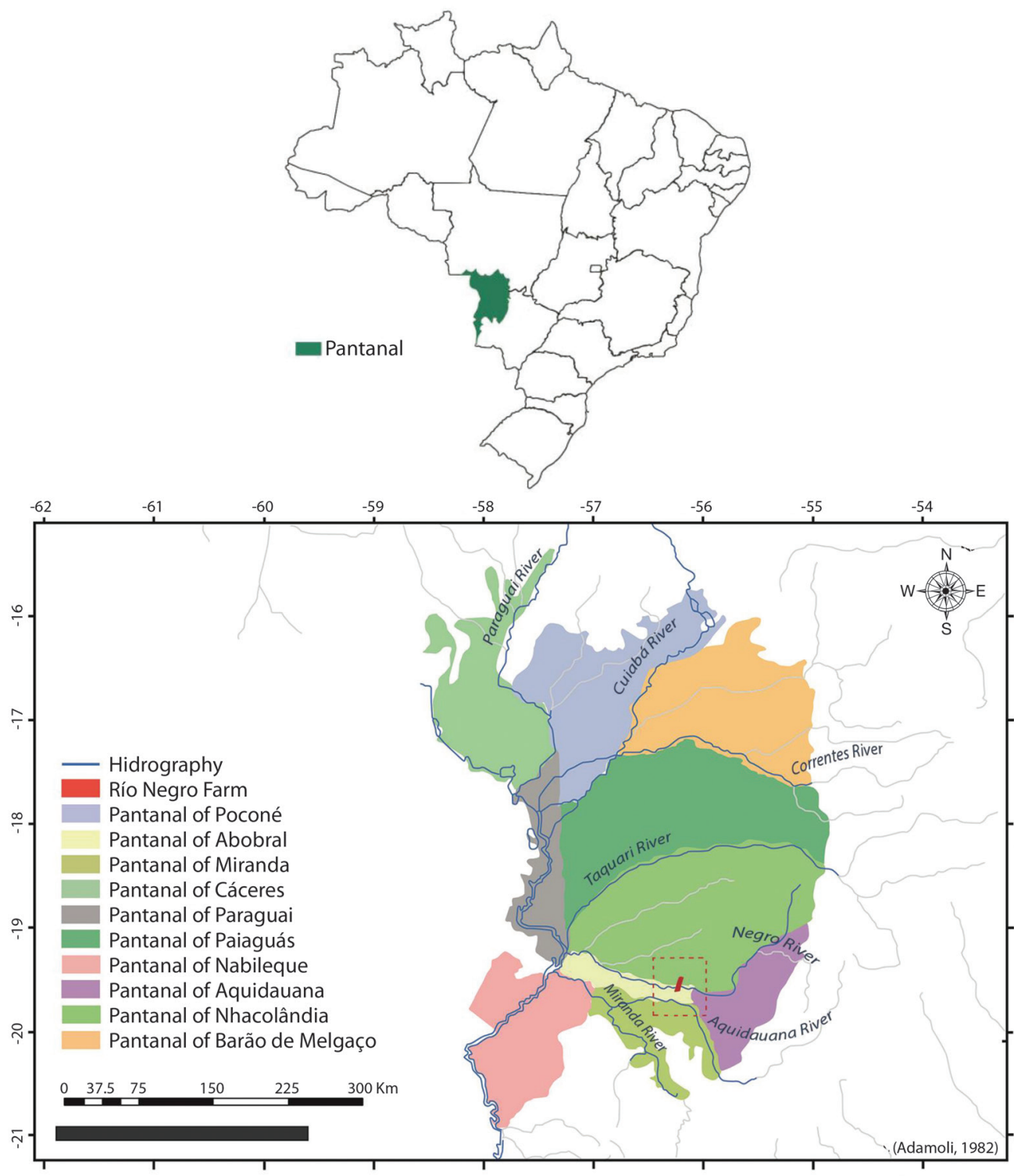

Fig. 1. A. Pantanal area in Brazil (after Reginaldo J. Donatelli). B. Different types of Pantanal and localization of the Fazenda Rio Negro (Red spot).

are distributed in a very heterogeneous matrix (Adámoli apud Por, 1995). The Fazenda Rio Negro contains 8004 hectares, of which 7000 belong to RPPN (Private Natural Heritage Reserve) Fazenda Rio Negro, where the sampling plots were concentrated.

The region has a tropical semiarid climate, with an average annual rainfall of $1180 \mathrm{~mm}$ and average temperature varying between 21 and $28^{\circ} \mathrm{C}$ (Marengo, Oliveira, \& Alves, 2016). In the Fazenda Rio Negro, the average annual temperature is $26.6{ }^{\circ} \mathrm{C}$, with a defined dry season between the months of April and September. The Fazenda Rio Negro shelters seven types of habitats, representing the main formations found in the sub-region of Pantanal wetlands: 


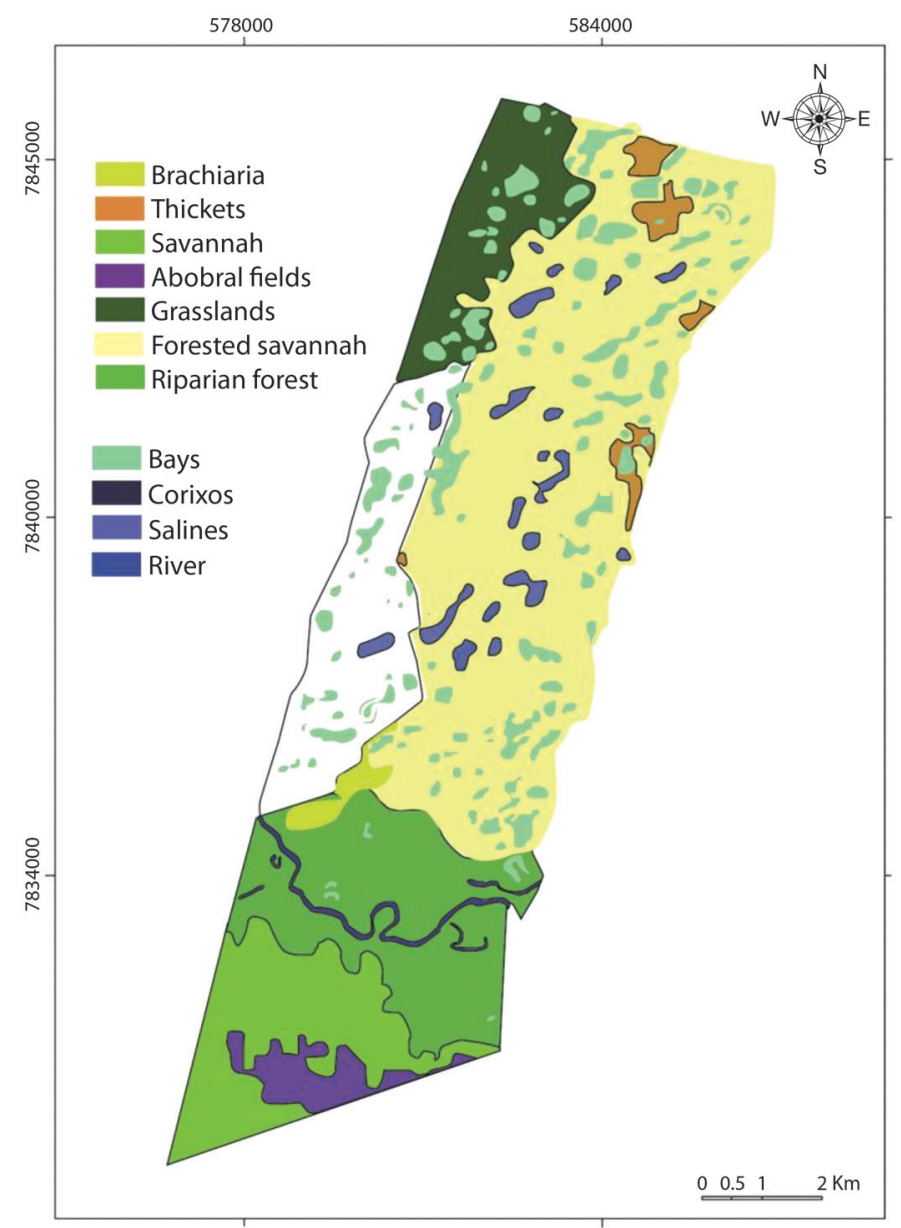

Fig. 2. Habitats found in the Fazenda Rio Negro, Pantanal of Nhecolândia (after D. Eaton).

riparian forests, savannah, forested savannah, grasslands, bays, salines and Negro river (Fig. 2). Riparian forests occur along watercourses throughout the drier regions of the Neotropics. These forests contain a diverse association of deciduous and semi-deciduous trees and are seldom larger than $100 \mathrm{~m}$ wide. Savannah is the widely used name for the non-forested vegetation that covers much of the Brazilian shield and ranges from open grasslands ("campo sujo") to dense woodlands (forested savannah, treated in this paper as a separate habitat type). Forested savannah is dense woodland consisting of trees and shrubs with thick, fireresistant bark, twisted trunks and large leaves; it contains a nearly continuous ground cover of grasses, sedges and forbs and is designated as dry forest or "cordilheiras" in the Pantanal region. Grasslands support a rich variety of herbaceous vegetation of more than 200 species of grasses and graminoid species; grasslands cover vast areas of Northern and Southeastern Bolivia and adjacent Brazil. Salines are small, rounded ponds, or typical "soda lakes" in which the predominant salt is sodium carbonate, with $\mathrm{pH}$ values that may reach 10 , and nitrogen that occurs almost exclusively in the form of ammonia (Por, 1995). Bays are natural freshwater spots, circular or elongated shaped and isolated by small elevations on ground, covered or not by vegetation. Waters from various bays connect to each other through small 
passages ("corixos" and "vazantes"), forming a coalescent system during the flood. The Rio Negro is a tributary of the Paraguay river, with $30 \mathrm{~km}$ extension that is between 10 and $50 \mathrm{~m}$ wide along its course.

Bird sampling: We used the linear transect method (Bibby, Burgess, \& Hill, 1992) for each of the seven habitats (riparian forest, savannah, forested savannah, grassland, bays, salines and river) from 2001 to 2004. During the 17 expeditions to the Fazenda Rio Negro, each habitat was visited twice. At each visit, we conducted two surveys (one in the morning and one in the afternoon), for two hours each period, for a total of 952 hours of linear transects performed in all habitats, (i.e., 4 hours per survey, seven habitats, two surveys per visit, 17 expeditions). Transects were distributed as follows: 2001 (January, April, June and August); 2002 (January, February, April, June, September); 2003 (January, August, November, December); 2004 (April, August, October and December). The transect methodology is widely used in bird studies in a variety of habitats and for different purposes. In general, transects are used in areas of easy access and locomotion as shown by Barrantes, Ocampo, Ramírez-Fernández and Fuchs (2016) in fragments of forest in Costa Rica. Silva and Rodrigues (2015) measured density and spatial distribution of shorebirds in the Brazilian Amazonian coast. Devault, Kubel and Rhodes (2009) monitored birding communities at small airports in the United States. Whitaker and Montevecchi (1996) surveyed breeding bird assemblages in riparian edge, nonriparian edge (clearcut or access road) and in forests in Canada. Herkert (1994) researched the influence of area and vegetation structure on breeding bird communities associated with grassland fragments in Illinois; and the transect method is also used in areas with intensive agriculture as studied by Atkinson, Fuller, Gillings and Vickery (2006).

Some general patterns were followed to develop the transects: 1) Routes were selected according to accessibility and were of a fixed length ( $2 \mathrm{~km}$ each) so each could be covered in a session of fieldwork (two hours); 2) surveys were done since dawn (around 6:00) and in late afternoon (from 05:00) to sunset; 3 ) they were fixed so that we could have replicas of each transect effected; 4) they were performed on consecutive days for each environment twice, totaling 10 days (with two separate teams to develop the samplings); 5) Each team was composed of six to ten participants depending on the location of the transect (the transect in the river was always composed by six participants according to the places available on the boat). 6) Care was taken not to record more than one contact for the same individual by monitoring location and dislocation. 7) Migratory species may be summer (wet season from October to March) or winter (dry season from April to September) visitors. 8) Equipment: we used 8 X30, 10X40 and 12X40 binoculars from Swarovski, Nikon and Bushnell brands; Swarovski ATS-65 HD 2.6 “/ 65 mm Spotting Scope and Ecotone 16.5-75X $80 \mathrm{~mm}$ for bird registration in salines and bays; Sony TCM 5000 EV, and TC-D5 Prof II for recordings of vocalizations with microphones Sennheiser M66 and ME67. We used ten mist-nets ranging from 20 to $36 \mathrm{~mm}$ and length ranging from 8,12 and $18 \mathrm{~m}$. The mist-nets were used as a complement to the qualitative study so that we could obtain maximum richness, particularly in closed environments where it was not possible to observe/listen to certain birds. It is a complementary study to the transect method, and was carried out simultaneously with another team. Classification of the species followed the official list of Brazilian birds, ruled by the Brazilian Committee of Ornithological Records (Piacentini et al., 2015).

Repeated measures ANOVAs were used to compare total abundance of birds among years, season and times of day because we repeated the surveys each year. A total of four repeated measures two-way ANOVAs were performed: 1) to evaluate the effect of the year, the time of day (morning or afternoon) and the interaction between year and time of day in the total abundance; 2) the effect of the year, the season (dry or wet) and the interaction 
between the year and the season in total abundance; 3) the effect of the year, the habitat and the interaction between year and habitat in the total abundance; and 4) the effect of the year, the categorized habitat (open, i.e., areas with fewer tree cover as grasslands; and closed, i.e., areas with greater tree cover, such as riparian forests and forested savannah) and the interaction between habitat and year in the total abundance. Once a statistically significant effect was identified, we used Tukey post-hoc test (for multiple comparison of measures). All tests were two-tailed, and the differences were considered significant at $\mathrm{P}<0.05$.

\section{RESULTS}

Richness: The richness registered was 201 species for the savannah, 87 in forested savannah, 116 in the riparian forest, 75 in grasslands, 92 in the salines, 120 in the bays and 64 in Rio Negro, accounting for 348 species in the Pantanal do Rio Negro (Appendix 1). About $80 \%$ of these species occurred in one or two habitats, $7 \%$ in three, $9 \%$ in four, $1 \%$ in five and less than $1 \%$ in all of them. There were still $2 \%$ of the species that did not belong to any specific habitat, because they generally occupied the air space (Appendix 1). The savannah showed the highest number of exclusive species (67 species), while only four exclusive species were recorded for the forested savannah. A total of 22 exclusive bird species were recorded in the grasslands, 25 in the riparian forests, 14 species in the river, nine in the salines and only two species at bays (Appendix 1).

We found significant variation on richness among years $\left(\mathrm{F}_{3,219}=14.757, \mathrm{P}<0.001\right)$, among habitats $\left(\mathrm{F}_{6,219}=30.886, \mathrm{P}<0.001\right)$, and in the interaction between different years and habitats $\left(\mathrm{F}_{17,219}=3.505, \mathrm{P}<0.001\right)$. The post-hoc Tukey test displayed clusters of habitats based on richness: one composed only by the grasslands, one composed by bays, forested savannah, salines and gallery forest, and the last one composed by savannah and river. When we examined variation between seasons, we found differences among years $\left(\mathrm{F}_{3,221}=3.576, \mathrm{P}=0.015\right)$ and on the interaction between different years and seasons $\left(\mathrm{F}_{3,221}\right.$ $=6.070, \mathrm{P}=0.001)$, but we did not find any variation between seasons $\left(\mathrm{F}_{1,221}=3.116, \mathrm{P}=\right.$ $0.078)$. Once again variation occured in $2004(\mathrm{t}$ $=-3.337, \mathrm{P}=0.002)$. We found no differences on richness among years $\left(\mathrm{F}_{3,219}=1.200, \mathrm{P}=\right.$ $0.311)$, between times of day $\left(\mathrm{F}_{1,219}=3.752, \mathrm{P}\right.$ $=0.054)$ and in the interaction between different years and times of day $\left(\mathrm{F}_{3,219}=2.491, \mathrm{P}=\right.$ 0.061) (Fig. 3 and Table 1).

Considering all the environments sampled, the families with the highest richness were Tyrannidae and Psittacidae, with 32 and 16 species, respectively, followed by Columbidae, Picidae and Emberizidae, each with 13 species. Twenty-five families were represented by only one or two species. The highest species richness of Tyrannidae (Passeriformes) and Psittacidae (non-Passeriformes) was recorded in the savannah, forested savannah and gallery forests. In the grasslands, more species of Emberezidae were registered. Ardeidae and Threskiornithidae were dominant in number of species in salinas, in the bays and in the river. Momotidae was restricted to the gallery forest, Alcedinidae standing out in the river and bays. Some tyrannids were restricted to one

TABLE 1

Richness of birds in the Pantanal for times of day and seasons between 2001 and 2004

\begin{tabular}{ccccc} 
Year & Morning & Afternoon & Dry & Wet \\
2001 & $35.34 \pm 20.20$ & $27.09 \pm 13.08$ & $32.81 \pm 16,17$ & $30.57 \pm 18.34$ \\
2002 & $35.85 \pm 12.81$ & $28.40 \pm 13.80$ & $32.89 \pm 13,55$ & $37.35 \pm 12.19$ \\
2003 & $32.88 \pm 11.80$ & $38.35 \pm 4.30$ & $36.27 \pm 9,24$ & $31.87 \pm 12.15$ \\
2004 & $39.90 \pm 14.23$ & $28.62 \pm 21.52$ & $32.29 \pm 14,72$ & $48.87 \pm 13.23$ \\
\hline
\end{tabular}

Values represent mean species number $\pm \mathrm{SD}$. 


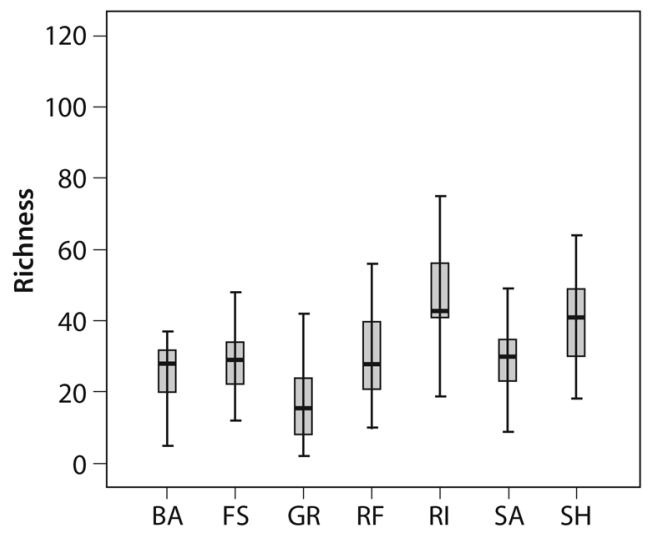

Fig. 3. Richness of birds for each different habitat in the Pantanal. Values represent mean \pm SD. BA - bays; FS forested savannah; $\mathrm{SH}$ - savannah; $\mathrm{RP}$ - riparian forest; GR-grasslands; RI - river; SA - salines.

or two environments, such as Cnemotriccus fuscatus and Lessonia rufa in the forested savannah, Gubernetes yetapa, Camptostoma obsoletum and Megarynchus pitangua in the savannah, Xolmis velatus in the grasslands, Philohydor lictor in the river and Machetornis rixosa in the salinas. Pitangus sulphuratus, on the other hand, was well distributed in the all environments.

Abundance: Total abundance of birds was not different among years $\left(\mathrm{F}_{3,219}=1.999, \mathrm{P}=\right.$ $0.115)$, times of day $\left(\mathrm{F}_{1,219}=2.066, \mathrm{P}=0.152\right)$ and between times of day when it was dependent upon the years $\left(\mathrm{F}_{3,219}=0.252, \mathrm{P}=0.680\right)$. However, it showed significant variation in the interaction between years and seasons $\left(\mathrm{F}_{3,219}=\right.$ $3.685, \mathrm{P}=0.013$ ) since 2004 showed significant differences in abundance between both seasons $(\mathrm{t}=-3.224, \mathrm{P}=0.002)$. Thus, it could be said that the dry season would attract more visiting birds to better exploit the resources in aquatic environments (rivers, bays, and salines) when the water level drops in these environments. On the other hand, the rain would delay this process, allowing the birds to be less concentrated in these aquatic environments. Another relevant factor in relation to the dry season is that many species of aquatic visiting birds nest on the edges

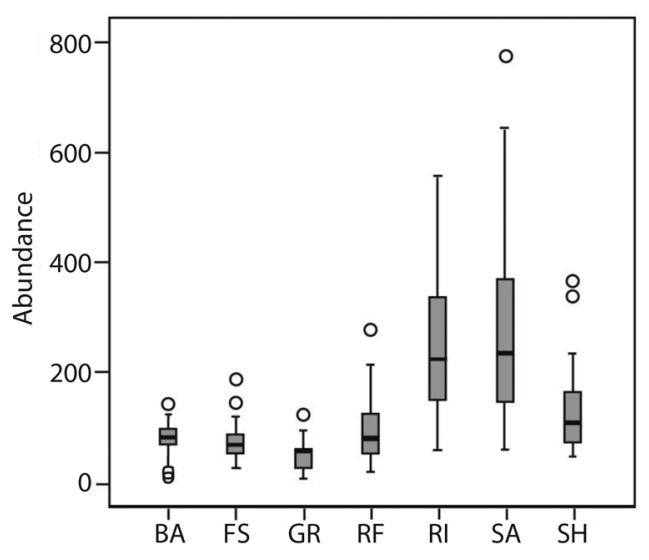

Fig. 4. Abundance of birds in the Pantanal. Values represent mean \pm SD. BA - bays; FS - forested savannah; SH savannah; RP- riparian forest; GR - grasslands; RI - river; $\mathrm{SA}-$ salines.

of aquatic environments and food is more easily obtained with the decrease of water.

Total abundance of birds was different among years $\left(\mathrm{F}_{3,219}=6.549, \mathrm{P}<0.001\right)$, among

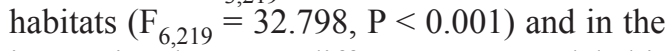
interaction between different years and habitats $\left(\mathrm{F}_{17,219}=3.115, \mathrm{P}<0.001\right)$. The post-hoc Tukey test showed two major groups: one composed by habitats with low abundance, such as grasslands, forested savannah, savannah, bays and riparian forests, and another one formed by salines and river, that have higher abundance (Fig. 4 and Table 2).

Psittacidae was the most abundant family in the region, with prominence in all environments. Recurvirostridae, a monospecific family, showed expressive abundance due to the dominance of Himantopus mexicanus in the salinas, followed by Ardeidae, Anatidae and Cracidae. Other families with high abundance were Tyrannidae, Columbidae, Thraupidae and Emberizidae, all in predominantly terrestrial environments. Among the most abundant species we registered Brotogeris chiriri standing out in all the sampled environments. Other species with great abundance in the different environments were Ortalis canicollis, Amazona aestiva, Dendrocygna viduata, Cantorchilus leucotis and Pitangus sulphuratus. The 30 most 
TABLE 2

Abundance of birds in the Pantanal for times of day and seasons between 2001 and 2004

\begin{tabular}{ccccc} 
Year & Morning & Afternoon & Dry & Wet \\
2001 & $182.82 \pm 95.04$ & $153.95 \pm 162.86$ & $202.15 \pm 190.93$ & $145.67 \pm 156.94$ \\
2002 & $181.14 \pm 127.71$ & $135.60 \pm 78.28$ & $194.62 \pm 151.20$ & $161.81 \pm 110.32$ \\
2003 & $176.09 \pm 113.07$ & $151.87 \pm 77.24$ & $182.86 \pm 112.52$ & $164.27 \pm 122.6$ \\
2004 & $160.20 \pm 109.41$ & $172.25 \pm 173.01$ & $120.11 \pm 84.82$ & $250.03 \pm 144.03$ \\
\hline
\end{tabular}

Values represent mean of number of birds detected $\pm \mathrm{SD}$.

abundant species together represented $61 \%$ of all records. Dendrocygna autumnalis was preferentially concentrated in the rivers and salines while Cairina moschata was frequently distributed in the bays. Anhinga anhinga and Nannopterum brasilianus were recorded almost exclusively in the river, except for some records of the second in the bays and salines. The Ardeidae were more frequent in the river, followed by the salines and expressively less common in the bays. Treskiornithidae were more frequent in the salinas while the Ciconiidae stood out in the river. The distribution of limnic species was heterogeneous among the three aquatic environments. Vanellus chilensis $(\mathrm{N}=206), H$. mexicanus $(\mathrm{N}=1712)$, Tringa flavipes $(\mathrm{N}=241), T$. melanoleuca $(\mathrm{N}=149)$ and Phaetusa simplex $(\mathrm{N}=197)$ were abundant in the salines. Jacana jacana $(\mathrm{N}=210)$ was abundant in bays, salines and grasslands. $P$. simplex was abundant in saline and common in the river, while $S$. superciliary and Chlidonias niger $(\mathrm{N}=130)$ had ample abundance only in the river.

Migratory species: A total of 98 species of migratory birds were registered in Pantanal of Rio Negro (Appendix 1). The vast majority of migratory species were recorded between June and September. The following were exceptions: Crotophaga major, a summer migratory species recorded only during the wet season; Anhinga anhinga, normally recorded in large numbers during summer (small numbers in winter); Nannopterum brasilianus, present in summer and the early dry season (winter in the Pantanal); and Phaetusa simplex (Gmelin, 1789), another species that migrates in summer. There is also Hirundo rustica Linnaeus, 1758, seen usually in large flocks during summer (wet season). Those typical of the rainy period (summer), with more than 100 recordings were N. brasilianus, P. simplex, Tachybaptus dominicus, C. major and Mesembrinibis cayennensis (Gmelin, 1789). At some time, any of these species can be recorded in small numbers in different seasons.

\section{DISCUSSION}

Naumburg (1930) was one of the pioneers in describing birds of the Pantanal, followed by Mitchell (1957). Cintra and Yamashita (1990) went a step further and described the habitats, distribution, and abundance of bird species in the Northern Pantanal. Brown (1986) analyzed the distribution and biogeographic affinities of over 650 bird species in the Pantanal. Dubs (1992) presented a catalogue of birds from Southwestern Brazil and bordering regions in the Pantanal region with almost 700 species of birds. The avifauna from Pantanal wetlands has the highest species richness among the wet areas in the World, sheltering approximately 460 species (Nunes \& Thomas, 2004a). Moreover, new species are added every year to the Pantanal list (Nunes et al., 2008). Figueira et al. (2006) found more bird species richness in forest areas, followed by savannahs and grasslands and floodable or aquatic fields. In terms of aquatic habitats, the diversity of bird community in the dry season varies significantly in the salines, followed by the bays and more stable in the Negro river. The Negro river, regardless of large annual amplitude of flow, is more seasonally stable since 
its riparian vegetation is continuous (not isolated) and constant (Donatelli et al., 2014). Our results showed the same pattern recorded by these authors in relation to aquatic habitats but this work, the first of its kind, will be a reference for further studies of birds in Pantanal, for various fields of research.

The temporal and spatial variation in the abundance of birds in the tropics has already been highlighted by several authors (Blake \& Loiselle, 1991) and the fluctuations in bird abundance are already known in Pantanal (Nunes \& Thomas, 2004a). Thus, as registered in the present work, in the dry season the abundance of birds was higher than in the wet period. The dry season is related to high availability of food and decrease in the volume of water in the wetland system (Por, 1995). On the other hand, Poulin, Lefebvre and McNeil (1993) registered lower abundances of birds at the beginning of the reproductive period in deciduous and dry forests in Venezuela, associating this to the low availability of food.

The spatial distribution of the animal diversity has also been explained in climate and vegetational structure (Cueto \& Casenave, 1999; Veech \& Crist, 2007). According to Farley, Ellis, Stuart \& Scott (2004) habitat variability is a determinant part of the structure and dynamics of a community of birds, because most of the species are closely related to specific habitats. We found that there was no significant variation in the abundance of birds in the same habitat in four years of data collection, but a great significant variation between different habitats was observed; this fact was expected, considering the peculiar characteristics of each habitat. So, in a regional scale, the factors that seem to influence bird abundance are habitat type, size, and diversity of habitats existing in a specific place (Rafe, Usher, \& Jefferson, 1985), being the heterogeneity of habitats a predominant factor in the determination of the number of birds' species (Rafe et al., 1985; Farley et al., 1994; Bailey et al., 2004; Blake, 2007). Figueira et al. (2006) found more bird species richness in forest areas, followed by savannahs and grasslands and floodable or aquatic fields. On the other hand, in terms of abundance, we observed that the open habitats, such as the salines and rivers had a higher abundance of birds than the other habitats (categorized as closed); a possible reason for this was a large concentration of species of shorebirds exploring food in these environments.

Figueira et al. (2006) analysed bird diversity of Pantanal wetlands in Mato Grosso and found three types of habitats with similar diversity: 1) forested habitats (forested savannah and riparian forests); 2) savannah (savannah sensu strict and grasslands); and 3) aquatic habitats (rivers, bays, corixos). Species which share distinct habitats may also indicate, indirectly, the potential flow of individuals and species among the different habitats and consequently, the complexity, the interconnectivity and the flexibility of interactions in the food chain. Thus, the heterogeneity of habitats is fundamental for the maintenance of the diversity of both aquatic and terrestrial birds (Figueira et al., 2006). On the other hand, our results also indicated that it seems quite remote that Pantanal wetlands share bird species with other habitat, except in particular conditions (river and riparian forests, salines and rivers). Results of abundance showed specificity and each habitat has its own importance in the whole context, notwithstanding the sharing of habitats.

Considering migratory species, Nunes and Tomas (2004b) listed 133 species of migratory birds with occurrence in the plains of the Pantanal wetlands. In this study 98 species, approximately $74 \%$ of all the migratory birds that occur in the plains of the Pantanal were registered. According to the reference chart from these authors, we have the following profile regarding the migratory birds in the Pantanal do Rio Negro: 1) Most of these species have aquatic habits; 2) approximately $40 \%$ are migrant from the American continent, and $32 \%$ from national territory; 3 ) approximately $15 \%$ come from Central America, North of South America and North America and $13 \%$ from the extreme South of South America; 4) None of them has been considered in situation that requires attention regarding 
conservation and 5) the vast majority has got unknown destination.

The results highlight some important issues regarding the abundance of birds in this region of Pantanal wetlands: a) The morning period and the dry season register the highest number of birds, regardless of the habitat; b) there are no significant differences in abundance in the same habitat along the years, but the habitats among themselves showed different total abundances.

In general, the results indicated that there is a relatively stable abundance in each habitat along years, but there is a clear difference in abundance among the habitats yearly, associated with their particularities. Pantanal of Rio Negro is an enormous complex of interconnected habitats on which the local community of birds depends. This diversity of habitats contributes to the high abundances recorded, as well as to the biome as a whole. Thus, additional studies on food availability in dry and wet seasons should be better explored in the future, either in this region or in other Pantanal regions. This fact could better explain the seasonal dynamics of the richness and abundance of birds in the Pantanal in general.

\section{ACKNOWLEDGMENTS}

We must acknowledge our immense debt to Earthwatch Institute for the opportunity to carry out the ornithological research Project in the Pantanal, and to the more than 300 volunteers who assisted us in the field from 2001 to 2004. Heartfelt thanks to Conservation International for logistic support at Fazenda Rio Negro. We also want to thank Alexine Keuroghlian and Don Eaton for their invaluable support in Campo Grande and at Fazenda Rio Negro; to Jeff Himmelstein for his assistance at all times and also for friendship. We are grateful to all staff at the Fazenda (Geni, Baiano, Celso, Seu Japão, Picolé, and Ico). We thank very much the reviewers of the manuscript who made valuable suggestions.

\section{RESUMEN}

Variación temporal y espacial en la riqueza y abundancia de la comunidad de aves del humedal Pantanal de Nhecolândia (Mato Grosso do Sul, Brazil). Los humedales del Pantanal representan una de las mayores llanuras de inundación del mundo, con variaciones climáticas extremas entre las estaciones seca y húmeda. La zona alberga una gran diversidad de hábitats, representando las principales formaciones encontradas en esta subregión de humedales del Pantanal: pastizales, sabanas, sabanas boscosas, bosques ribereños, bahías y salinas, y el propio Río Negro. La variabilidad del hábitat es una parte determinante de la estructura y dinámica de la comunidad de aves, ya que la mayoría de las especies están estrechamente relacionadas con hábitats específicos. Estudiamos la abundancia de especies de aves de 2001 a 2004 en la Fazenda Río Negro, Aquidauana, Brasil. La abundancia se comparó entre los cuatro años consecutivos, las estaciones (seca y húmeda), la hora del día (mañana y tarde) y también entre siete hábitats diferentes, para determinar la variación en los patrones de distribución y hábitats utilizados por las aves. Para ello, se utilizó el método de transectos lineales en cada uno de los siete hábitats, y se registraron las abundancias de aves para obtener la riqueza. La riqueza registrada en el mosaico de hábitats fue de 201 especies para la sabana, 87 sabana boscosa, 116 bosque ribereño, 75 en pastizales, 120 en bahías, 92 en salinas y 64 en el río Negro, con 348 especies en el Pantanal de Río Negro. En total, se registraron 98 especies de aves migratorias. Los resultados destacaron algunas cuestiones importantes con respecto a la abundancia total de aves en Nhecolândia: Psittacidae fue la familia más abundante en la región, con prominencia en todos los ambientes. Recurvirostridae, una familia monoespecífica, mostró abundancia significativa debido a la dominancia de Himantopus mexicanus en las salinas, seguido por Ardeidae, Anatidae y Cracidae. Otras familias con gran abundancia fueron: Tyrannidae, Columbidae, Thraupidae y Emberizidae, todas en ambientes predominantemente terrestres. Además: a) Se registró el mayor número de ejemplares en el período de la mañana y en la estación seca, independientemente del hábitat; B) no hubo diferencias en la abundancia en el mismo hábitat a lo largo de los años, pero la abundancia fue diferente entre los hábitats. En general, los resultados indicaron que hay una población de aves relativamente estable en cada hábitat a lo largo del ciclo anual, pero hubo diferencias en la abundancia entre los hábitats.

Palabras clave: pantanal, comunidad de aves, mosaico de hábitats, Mato Grosso do Sul.

\section{REFERENCES}

Alho, C. J. R., Lacher Jr., T. E., \& Gonçalves, H. C. (1988). Habitat degradation in the Pantanal ecosystem. BioScience, 38, 164-171. 
Atkinson, P. W., Fuller, R. A., Gillings, S., \& Vickery, J. A. (2006). Counting birds on farmland habitats in winter. Bird Study, 53, 303-309.

Bailey, S. A., Horner-Devine, M. C., Luck, G., Moore, L. A., Carney, K. M., Anderson, S., Betrus, C., \& Fleishman, E. (2004). Primary productivity and species richness: relationships among functional guilds, residency groups and vagility classes at multiple spatial scales. Ecography, 27, 207-217.

Barrantes, G., Ocampo, D., Ramírez-Fernández, J. D. \& Fuchs, E. J. (2016). Effect of fragmentation on the Costa Rican dry forest avifauna. Peer J, DOI $10.7717 /$ peerj. 2422

Bibby, C. J., Burgess, N. D., \& Hill, D. A. (1992). Bird Census Techniques. San Diego: Academic Press Inc.

Blake, J. G. (2007). Neotropical forest bird communities: a comparison of species richness and composition at local and regional scales. The Condor, 109, 237-255.

Blake, J. G., \& Loiselle, B. A. (1991). Variation in resource abundance affects capture rates of birds in three lowland habitats in Costa Rica. The Auk, 108, 114-130.

Brown, K. S. JR. (1986). Zoogeografia da região do Pantanal Matogrossense. In Anais do I Simpósio sobre recursos naturais e sócioeconômicos do Pantanal (137-138 pp.). EMBRAPA - DDT, Brasília, Brasil.

Cintra, R. \& Yamashita, C. (1990). Hábitats, abundância e ocorrência das espécies de aves do Pantanal de Poconé, Mato Grosso, Brasil. Papéis Avulsos Zool., $37,1-21$.

Cueto, V. R., \& Casenave, J. L. (1999). Determinants of bird species richness: role of climate and vegetation structure at a regional scale. Journal of Biogeography, 26, 487-492.

Devaut, T., Kubel, J., \& Rhodes Jr., O. (2009). Habitat and Bird Communities at Small Airports in the Midwestern USA. Wildlife Damage Management Conferences - Proceedings, 115, 137-145.

Donatelli, R. J., Posso, S. R., \& Toledo, M. C. B. (2014). Distribution, composition and seasonality of aquatic birds in the Nhecolândia sub-region of South Pantanal, Brazil. Brazilian Journal of Biology/Revista Brasileira de Biologia, 74, 844-853.

Dubs, B. (1992). Birds of southwestern Brazil: catalogue and guide to the birds of the Pantanal of Mato Grosso and its border areas. Kusnacht, Switzerland: Betrona-Verlag.

Farley, G. H., Ellis, L. M., Stuart, J. N., \& Scott Jr, N. J. (1994). Avian species richness in differentaged stands of Riparian Forest along the Middle Rio Grande, New Mexico. Conservation Biology, 8, 1098-1108.
Figueira, J. E. C., Cintra, R., Viana, L. R., \& Yamashita, C. (2006). Spatial and temporal patterns of bird species diversity in the Pantanal of Mato Grosso, Brazil: implications for conservation. Brazilian Journal of Biology/Revista Brasileira de Biologia, 66, 393-404.

Herkert, J. R. (1994). The effects of habitat fragmentation on midwestern grassland bird communities. Ecological Applications, 4, 461-471.

Marengo, J. A., Oliveira, G. S., \& Alves, L. M. (2016). Climate changes scenarios in the Pantanal. In I. Bergier, \& M. L. Assine (Eds), Dynamics of the Pantanal Wetland in South America (pp. 227-238). Switzerland: Springer International Publishing.

Mitchell, M. K. H. (1957). Observations on birds of southeastern Brazil. Toronto: University of Toronto Press.

Naumburg, E. M. B. (1930). The birds of Mato Grosso, Brazil. Bulletin American Museum Natural History, 60, 1-432.

Nunes, A. P., Tizianel, F. A. T., \& Tomas, W. M. (2006). Aves ameaçadas ocorrentes no Pantanal. Embrapa Pantanal - Documentos, 83, 41.

Nunes, A. P., \& Tomas, W. M. (2004a). Análise preliminar das relações biogeográficas da avifauna do Pantanal com biomas adjacentes. In do, A. (Translator), Simpósio sobre Recursos Naturais E Sócio-Econômicos Do Pantanal. Corumbá: Embrapa Pantanal.

Nunes, A. P., \& Tomas, W. M. (2004b). Aves migratórias ocorrentes no Pantanal: caracterização e conservação. Embrapa Pantanal - Documentos, 62, 27.

Nunes, A. P., Silva, P. A., \& Tomas, W. M. (2008). Novos registros de aves para o Pantanal, Brasil. Revista Brasileira de Ornitologia, 16, 160-164.

Piacentini, V. Q., Aleixo, A., Agne, C. E., Maurício, G. N., Pacheco, J. F., Bravo, G. A., ... Cesari, E. (2015). Annotated checklist of the birds of Brazil by the Brazilian Ornithological Records Committee / Lista comentada das aves do Brasil pelo Comitê Brasileiro de Registros Ornitológicos. Revista Brasileira de Ornitologia, 23, 91-298.

Por, F. D. (1995). The Pantanal of Mato Grosso (Brazil): World's largest wetlands. In H. J. Dumont, \& M. J. A. Werger (Eds.), Monographiae Biologicae (Vol. 73). Dordrecht, Netherlands: Kluwer.

Pott, A., \& Silva, J. S. V. (2015). Terrestrial and aquatic vegetation diversity of the Pantanal wetland. In I. Bergier, \& M. L. Assine (Eds.), Dynamics of the Pantanal Wetland in South America (pp. 83-110). Switzerland: Springer International Publishing.

Poulin, B., Lefebvre, G., \& McNeil, R. (1993). Variations in bird abundance in tropical arid and semi-arid habitats. Ibis, 135, 432-441. 
Rafe, R. W., Usher, M. B., \& Jefferson, R. G. (1985). Birds on reserves: the influence of area and habitat on species richness. Journal of Applied Ecology, $22,327-335$.

Ratter, J. A., Pott, A., Pott, V. J., Cunha, C. N., \& Haridasan, M. (1988). Observations on wood vegetation types in the Pantanal and at Corumbá, Brazil. Notes from the Royal Botanic Garden, Edinburgh, 45, 503-525.

Resende, I. L M., Araújo, G. M., Oliveira, A. P. A., Oliveira, A. P., \& Ávila, R. S, Jr. (2004). A comunidade vegetal e as características abióticas de um campo de murundu em Uberlândia, MG. Acta Botanica Brasilica, 18, 9-17.

Rodela, L. G. (2006). Unidades de vegetação e pastagens nativas do Pantanal da Nhecolândia, Mato Grosso do Sul (Doctoral dissertation). Retrieved from Departamento de Geografia da Faculdade de Filosofia, Letras e Ciências Humanas da Universidade de São Paulo.
Silva, L. M. R., \& Rodrigues, A. A. F. (2015). Densidade e distribuição espacial de aves limícolas em habitats de forrageio na costa amazônica brasileira. Ornithologia, 8, 17-21.

Tomás, W. M., de Salis, S. M., Catella, A., Santos, S., \& Nunes, A. (2007) Biodiversidade na região inundada pelo Rio Taquari. Corumbá: Embrapa Pantanal.

Tubelis, D. P., \& Tomas, W. M. (2003). Bird species of the wetland, Brazil. Ararajuba, 11, 5-37.

Veech, J. A., \& Crist, T. O. (2007). Habitat and climate heterogeneity maintain beta-diversity of birds among landscapes within ecoregions. Global Ecology and Biogeography, 16, 650-656.

Whitaker, D. M., \& Montevecchi, W. A. (1997). Breeding bird assemblages associated with riparian, interior forest, and nonriparian edge habitats in a balsam fir ecosystem. Canadian Journal Forest Research, $27,1159-1167$. 


\section{APPENDIX 1}

Bird species recorded in the Pantanal, Fazenda Rio Negro, from 2001 to 2004

\begin{tabular}{|c|c|c|c|c|c|c|}
\hline Rheidae & RF & $\mathrm{SH}$ & FS & BA & SA & GR \\
\hline Rhea americana Greater Rhea (Linnaeus, 1758) & & $\mathrm{X}$ & & & $\mathrm{X}$ & $\mathrm{X}$ \\
\hline \multicolumn{7}{|l|}{ Tinamidae } \\
\hline Crypturellus undulatus Undulated Tinamou (Temminck, 1815) & $\mathrm{X}$ & $\mathrm{X}$ & $\mathrm{X}$ & $\mathrm{X}$ & & \\
\hline Crypturellus parvirostris Small-billed Tinamou (Wagler, 1827) & & $\mathrm{X}$ & & $\mathrm{X}$ & & $\mathrm{X}$ \\
\hline Rhynchotus rufescens Red-winged Tinamou (Temminck, 1815) & & & & & & $\mathrm{X}$ \\
\hline \multicolumn{7}{|l|}{ Podicipedidae } \\
\hline Tachybaptus dominicus Least Grebe ${ }^{\mathrm{M}}$ (Linnaeus, 1766) & & & & $\mathrm{X}$ & $\mathrm{X}$ & \\
\hline Podilymbus podiceps Pied-billed Grebe ${ }^{\mathrm{V}}$ (Linnaeus, 1758) & & & & $\mathrm{X}$ & $\mathrm{X}$ & \\
\hline \multicolumn{7}{|l|}{ Phalacrocoracidae } \\
\hline Nannopterum brasilianus Neotropic Cormorant ${ }^{\mathrm{M}}$ (Gmelin, 1789) & & & & $\mathrm{X}$ & $\mathrm{X}$ & \\
\hline \multicolumn{7}{|l|}{ Anhingidae } \\
\hline Anhinga anhinga Anhinga (Linnaeus, 1766) & & & & $\mathrm{X}$ & $\mathrm{X}$ & \\
\hline \multicolumn{7}{|l|}{ Ardeidae } \\
\hline Ardea cocoi White-necked Heron Linnaeus, 1766 & & & & $\mathrm{X}$ & $\mathrm{X}$ & \\
\hline Ardea alba Great Egret Linnaeus, 1758 & & & & $\mathrm{X}$ & $\mathrm{X}$ & \\
\hline Egretta thula Snowy Egret ${ }^{\mathrm{M}}$ (Molina, 1782) & & & & $\mathrm{X}$ & $\mathrm{X}$ & \\
\hline Egretta caerulea Little Blue Heron (Linnaeus, 1758) & & & & & $\mathrm{X}$ & \\
\hline Butorides striata Striated Heron (Linnaeus, 1758) & & & & $\mathrm{X}$ & $\mathrm{X}$ & \\
\hline \multicolumn{7}{|l|}{ Agamia agami Chestnut-bellied Heron (Gmelin, 1789) } \\
\hline Bubulcus ibis Cattle Egret (Linnaeus, 1758) & & $\mathrm{X}$ & & & & $\mathrm{X}$ \\
\hline Syrigma sibilatrix Whistling Heron (Temminck, 1824) & & & & $\mathrm{X}$ & $\mathrm{X}$ & \\
\hline \multicolumn{7}{|l|}{ Pilherodius pileatus Capped Heron (Boddaert, 1783) } \\
\hline Nycticorax nycticorax Black-crowned Night-Heron (Linnaeus, 1758) & & & & $\mathrm{X}$ & & \\
\hline Tigrisoma lineatum Rufescent Tiger-Heron (Boddaert, 1783) & & & & $\mathrm{X}$ & $\mathrm{X}$ & \\
\hline \multicolumn{7}{|l|}{ Botaurus pinnatus Pinnated Bittern ${ }^{\mathrm{M}}$ (Wagler, 1829) } \\
\hline \multicolumn{7}{|l|}{ Cochlearius cochleariusBoat-billed Heron (Linnaeus, 1766) } \\
\hline \multicolumn{7}{|l|}{ Threskiornithidae } \\
\hline Theristicus caerulescensPlumbeous Ibis (Vieillot, 1817) & & & & $\mathrm{X}$ & $\mathrm{X}$ & $\mathrm{X}$ \\
\hline Theristicus caudatus Buff-necked Ibis (Boddaert, 1783) & & & & $\mathrm{X}$ & $\mathrm{X}$ & $\mathrm{X}$ \\
\hline Mesembrinibis cayennensis Green Ibis ${ }^{\mathrm{M}}$ (Gmelin, 1789) & & & & $\mathrm{X}$ & $\mathrm{X}$ & \\
\hline Phimosus infuscatus Whispering Ibis ${ }^{\mathrm{M}}$ (Lichtenstein, 1823) & & & & $\mathrm{X}$ & $\mathrm{X}$ & \\
\hline Plegadis chihi White-faced Ibis ${ }^{\mathrm{M}}$ (Vieillot, 1817) & & & & $\mathrm{X}$ & $\mathrm{X}$ & \\
\hline Platalea ajaja Roseate Spoonbill Linnaeus, 1758 & & & & $\mathrm{X}$ & $\mathrm{X}$ & \\
\hline \multicolumn{7}{|l|}{ Ciconiidae } \\
\hline Mycteria americana Wood Stork Linnaeus, 1758 & & & & $\mathrm{X}$ & $\mathrm{X}$ & $\mathrm{X}$ \\
\hline Ciconia maguari Maguari Stork (Gmelin, 1789) & & & & $\mathrm{X}$ & $\mathrm{X}$ & $\mathrm{X}$ \\
\hline Jabiru mycteria Jabiru (Lichtenstein, 1819) & & & & $\mathrm{X}$ & $\mathrm{X}$ & $X$ \\
\hline \multicolumn{7}{|l|}{ Cathartidae } \\
\hline Coragyps atratus Black Vulture (Bechstein, 1793) & & & & $\mathrm{X}$ & & \\
\hline Cathartes aura Turkey Vulture (Linnaeus, 1758) & & & & $\mathrm{X}$ & & \\
\hline \multicolumn{7}{|l|}{ Cathartes burrovianus Lesser yellow-headed Vulture Cassin, 1845} \\
\hline \multicolumn{7}{|l|}{ Sarcoramphus papa King Vulture (Linnaeus, 1758) } \\
\hline \multicolumn{7}{|l|}{ Anatidae } \\
\hline Dendrocygna bicolor Fulvous Whisting-Duck ${ }^{\mathrm{M}}$ (Vieillot, 1816) & & & & $\mathrm{X}$ & $\mathrm{X}$ & \\
\hline Dendrocygna viduata White-faced Whistilig Duck ${ }^{\mathrm{M}}$ (Linnaeus, 1766) & & & & $\mathrm{X}$ & $\mathrm{X}$ & \\
\hline Dendrocygna autumnalis Black-bellied Whistling Duck ${ }^{\mathrm{M}}$ (Linnaeus, 1758) & & & & $\mathrm{X}$ & $\mathrm{X}$ & \\
\hline
\end{tabular}


APPENDIX 1 (Continued)

\begin{tabular}{|c|c|c|c|c|c|c|}
\hline Rheidae & $\mathrm{RF}$ & $\mathrm{SH}$ & FS & $\mathrm{BA}$ & SA & GR \\
\hline Coscoroba coscoroba Coscoroba Swan ${ }^{\mathrm{V}}$ (Molina, 1782) & & & & $\mathrm{X}$ & $\mathrm{X}$ & \\
\hline Callonetta leucophrys Ringed Teal ${ }^{\mathrm{M}}$ (Vieillot, 1816) & & & & & $\mathrm{X}$ & \\
\hline Amazonetta brasiliensis Brazilian Teal (Gmelin, 1789) & & & & $\mathrm{X}$ & $\mathrm{X}$ & \\
\hline Sarkidiornis sylvicola Comb Duck ${ }^{\mathrm{M}}$ Ihering \& Ihering, 1907 & & & & & $\mathrm{X}$ & \\
\hline Cairina moschata Muskovy Duck (Linnaeus, 1758) & $\mathrm{X}$ & $\mathrm{X}$ & $\mathrm{X}$ & $\mathrm{X}$ & $\mathrm{X}$ & \\
\hline \multicolumn{7}{|l|}{ Anhimidae } \\
\hline Chauna torquata Southern Screamer (Oken, 1816) & $\mathrm{X}$ & & & $\mathrm{X}$ & $\mathrm{X}$ & \\
\hline \multicolumn{7}{|l|}{ Accipitridae } \\
\hline Elanus leucurus White-tailed Kite (Vieillot, 1818) & $\mathrm{X}$ & $\mathrm{X}$ & & & & \\
\hline Gampsonyx swainsoni Pearl Kite ${ }^{\mathrm{V}}$ Vigors, 1825 & $\mathrm{X}$ & $\mathrm{X}$ & & & & \\
\hline Elanoides forficatus Swallow-tailed Kite (Linnaeus, 1758) & $\mathrm{X}$ & $\mathrm{X}$ & & & & \\
\hline Leptodon cayanensis Gray-headed Kite (Latham, 1790) & $\mathrm{X}$ & & & & & \\
\hline Chondrohierax uncinatus Hook-billed Kite ${ }^{\mathrm{V}}$ (Temminck, 1822) & & $\mathrm{X}$ & & & & \\
\hline Ictinia plumbea Plumbeous Kite (Gmelin, 1788) & $\mathrm{X}$ & $\mathrm{X}$ & & $\mathrm{X}$ & & \\
\hline Rostrhamus sociabilis Snail Kite (Vieillot, 1817) & & & & $\mathrm{X}$ & $\mathrm{X}$ & \\
\hline Geranoaetus albicaudatus White-tailed Hawk (Vieillot, 1816) & & $\mathrm{X}$ & & & & \\
\hline Buteo albonotatus Zone-tailed Hawk Kaup, 1847 & & $\mathrm{X}$ & & & & \\
\hline Buteo brachyurus Short-tailed Hawk Vieillot, 1816 & & $\mathrm{X}$ & & & & \\
\hline Buteo nitidus Gray Hawk (Latham, 1790) & & $\mathrm{X}$ & & & & \\
\hline Rupornis magnirostris Roadsipe Hawk (Gmelin, 1788) & $\mathrm{X}$ & $\mathrm{X}$ & $\mathrm{X}$ & $\mathrm{X}$ & $\mathrm{X}$ & $\mathrm{X}$ \\
\hline Parabuteo unicinctus Harris's Hawk ${ }^{\mathrm{V}}$ (Temminck, 1824) & & $\mathrm{X}$ & & & & \\
\hline Busarellus nigricollis Black-collared Hawk (Latham, 1790) & $\mathrm{X}$ & $\mathrm{X}$ & $\mathrm{X}$ & $\mathrm{X}$ & $\mathrm{X}$ & $\mathrm{X}$ \\
\hline Heterospizias meridionalis Savannah Hawk (Latham, 1790) & & $\mathrm{X}$ & $\mathrm{X}$ & $\mathrm{X}$ & $\mathrm{X}$ & $\mathrm{X}$ \\
\hline \multicolumn{7}{|l|}{ Urubitinga urubitinga Great Black Hawk (Gmelin, 1788) } \\
\hline Urubitinga coronata Crowned Solitary Eagle $\mathrm{VU} / \mathrm{V}$ (Vieillot, 1817) & & $\mathrm{X}$ & & & & \\
\hline Geranospiza caerulescens Crane Hawk (Vieillot, 1817) & & $\mathrm{X}$ & & & & \\
\hline \multicolumn{7}{|l|}{ Pandionidae } \\
\hline Pandion haliaetus Osprey ${ }^{\mathrm{M}}$ (Linnaeus, 1758) & $\mathrm{X}$ & & & & & \\
\hline \multicolumn{7}{|l|}{ Falconidae } \\
\hline Herpetotheres cachinnans Laughing Falcon (Linnaeus, 1758) & $\mathrm{X}$ & $\mathrm{X}$ & & $\mathrm{X}$ & & \\
\hline Micrastur semitorquatus Collared Forest-Falcon (Vieillot, 1817) & $\mathrm{X}$ & & & & & \\
\hline Micrastur ruficollis Barred Forest-Falcon (Vieillot, 1817) & $\mathrm{X}$ & & & & & \\
\hline Milvago chimachima Yellow-headed Caracara (Vieillot, 1816) & $\mathrm{X}$ & $\mathrm{X}$ & $\mathrm{X}$ & $\mathrm{X}$ & $\mathrm{X}$ & $\mathrm{X}$ \\
\hline Caracara plancus Crested Caracara (Miller, 1777) & $\mathrm{X}$ & $\mathrm{X}$ & $\mathrm{X}$ & $\mathrm{X}$ & $\mathrm{X}$ & $\mathrm{X}$ \\
\hline Falco rufigularis Bat Falcon (Daudin, 1800) & & & & & $\mathrm{X}$ & \\
\hline Falco femoralis Aplomado Falcon (Temminck, 1822) & & $\mathrm{X}$ & & & & \\
\hline Falco sparverius American Kestrel (Linnaeus, 1758) & & & & & & $\mathrm{X}$ \\
\hline \multicolumn{7}{|l|}{ Cracidae } \\
\hline Ortalis canicollis Chaco Chachalaca (Wagler, 1830) & $\mathrm{X}$ & & $\mathrm{X}$ & $\mathrm{X}$ & $\mathrm{X}$ & \\
\hline Aburria cumanensis Blue-throated Piping-Guan (Jacquin, 1784) & $\mathrm{X}$ & & $\mathrm{X}$ & $\mathrm{X}$ & & \\
\hline Crax fasciolataBare-faced Curassow (Spix, 1825) & $\mathrm{X}$ & $\mathrm{X}$ & $\mathrm{X}$ & $\mathrm{X}$ & $\mathrm{X}$ & \\
\hline \multicolumn{7}{|l|}{ Aramidae } \\
\hline Aramus guarauna Limpkin (Linnaeus, 1766) & & & & $\mathrm{X}$ & $\mathrm{X}$ & $X$ \\
\hline \multicolumn{7}{|l|}{ Rallidae } \\
\hline Pardirallus nigricansBlackish Rail (Vieillot, 1819) & & & & & & $\mathrm{X}$ \\
\hline Aramides cajaneusGrey-necked Wood-Rail (Statius Muller, 1776) & $\mathrm{X}$ & & & $\mathrm{X}$ & & \\
\hline Mustelirallus albicollis Ash-throated Crake (Vieillot, 1819) & & & & & & $X$ \\
\hline
\end{tabular}




\begin{tabular}{|c|c|c|c|c|c|c|}
\hline Rheidae & $\mathrm{RF}$ & $\mathrm{SH}$ & FS & $\mathrm{BA}$ & SA & GR \\
\hline Coturnicops notatus Speckled crake (Gould, 1841) & & & & & & $\mathrm{X}$ \\
\hline Gallinula galeata Common Moorhen (Lichtenstein, 1818) & & & & & & $\mathrm{X}$ \\
\hline Porphyrio martinicusPurple Gallinule (Linnaeus, 1766) & & & & & & $\mathrm{X}$ \\
\hline Porphyrio flavirostris Azure Gallinule (Gmelin, 1789) & & & & & & $\mathrm{X}$ \\
\hline \multicolumn{7}{|l|}{ Heliornithidae } \\
\hline \multicolumn{7}{|l|}{ Heliornis fulica Sungreebe (Boddaert, 1783) } \\
\hline \multicolumn{7}{|l|}{ Cariamidae } \\
\hline Cariama cristata Red-legged Seriema (Linnaeus, 1766) & & $\mathrm{X}$ & & $\mathrm{X}$ & & $\mathrm{X}$ \\
\hline \multicolumn{7}{|l|}{ Jacanidae } \\
\hline Jacana jacana Wattled Jacana (Linnaeus, 1766) & & & & $\mathrm{X}$ & $\mathrm{X}$ & $\mathrm{X}$ \\
\hline \multicolumn{7}{|l|}{ Charadriidae } \\
\hline Vanellus chilensisSouthern Lapwing (Molina, 1782) & $\mathrm{X}$ & $\mathrm{X}$ & & $\mathrm{X}$ & $\mathrm{X}$ & $\mathrm{X}$ \\
\hline Vanellus cayanus Pied Lapwing ${ }^{\mathrm{M}}$ (Latham, 1790) & & & & $\mathrm{X}$ & & \\
\hline Charadrius collaris Collared Plover (Vieillot, 1818) & & & & & & $\mathrm{X}$ \\
\hline \multicolumn{7}{|l|}{ Scolopacidae } \\
\hline Tringa solitariaSolitary Sandpiper (Wilson, 1813) & & & & $\mathrm{X}$ & $\mathrm{X}$ & \\
\hline Tringa flavipes Lesser Yellowlegs (Gmelin, 1789) & & & & & $\mathrm{X}$ & \\
\hline Tringa melanoleucaGreater Yellowlegs (Gmelin, 1789) & & & & $\mathrm{X}$ & $\mathrm{X}$ & \\
\hline Actitis macularius Spotted Sandpiper (Linnaeus, 1766) & & & & & $\mathrm{X}$ & \\
\hline Calidris melanotos Pectoral Sandpiper ${ }^{\mathrm{M}}$ (Vieillot, 1819) & & & & & $\mathrm{X}$ & \\
\hline Bartramia longicauda Upland Sandpiper ${ }^{\mathrm{M}}$ (Bechstein, 1812) & & & & & $\mathrm{X}$ & \\
\hline Gallinago paraguaiaeMagellan Snipe (Vieillot, 1816) & & & & & $\mathrm{X}$ & \\
\hline Phalaropus tricolor Wilson's Phalatrope ${ }^{\mathrm{M}}$ (Vieillot, 1819) & & & & & $\mathrm{X}$ & \\
\hline \multicolumn{7}{|l|}{ Recurvirostridae } \\
\hline Himantopus melanurus White-backed Stilt Vieillot, 1817 & & & & & $\mathrm{X}$ & \\
\hline \multicolumn{7}{|l|}{ Sternidae } \\
\hline Phaetusa simplexLarge-billed Tern (Gmelin, 1789) & & & & $\mathrm{X}$ & $\mathrm{X}$ & \\
\hline Sternula superciliarisYellow-billed Tern (Vieillot, 1819) & & & & $\mathrm{X}$ & $\mathrm{X}$ & \\
\hline \multicolumn{7}{|l|}{ Rynchopidae } \\
\hline \multicolumn{7}{|l|}{ Rynchops niger ${ }^{\mathrm{b}}$ Black Skimmer ${ }^{\mathrm{M}}$ Linnaeus, 1758} \\
\hline \multicolumn{7}{|l|}{ Columbidae } \\
\hline Patagioenas picazuro Picazuro Pigeon (Temminck, 1813) & $\mathrm{X}$ & $\mathrm{X}$ & $\mathrm{X}$ & $\mathrm{X}$ & & $\mathrm{X}$ \\
\hline Patagioenas cayennensis Pale-vented Pigeon (Bonnaterre, 1792) & $\mathrm{X}$ & $\mathrm{X}$ & $\mathrm{X}$ & $\mathrm{X}$ & & $\mathrm{X}$ \\
\hline Zenaida auriculata Eared Dove (Des Murs, 1847) & & $\mathrm{X}$ & & & & $\mathrm{X}$ \\
\hline Columbina minuta Blue Ground-Dove (Linnaeus, 1766) & $\mathrm{X}$ & $\mathrm{X}$ & & & & $\mathrm{X}$ \\
\hline Columbina talpacoti ${ }^{\text {}}$ Ruddy Ground-Dove (Temminck, 1811) & & $\mathrm{X}$ & & $X$ & & $\mathrm{X}$ \\
\hline Columbina picui Picui Ground Dove (Temminck, 1813) & & $\mathrm{X}$ & & & & $\mathrm{X}$ \\
\hline Claravis pretiosa Blue-eyed Groud-Dove (Ferrari-Perez, 1886) & $\mathrm{X}$ & $\mathrm{X}$ & & & & \\
\hline Uropelia campestris Long-Tailed Ground Dove (Spix, 1825) & & $\mathrm{X}$ & & & & $\mathrm{X}$ \\
\hline Columbina squammata Scaled Dove (Lesson, 1831) & & $\mathrm{X}$ & & $\mathrm{X}$ & & $\mathrm{X}$ \\
\hline Leptotila verreauxi ${ }^{b}$ White-tipped Dove Bonaparte, 1855 & $\mathrm{X}$ & $\mathrm{X}$ & & $\mathrm{X}$ & & \\
\hline Leptotila rufaxilla Grey-fronted Dove (Richard \& Bernard, 1792) & $\mathrm{X}$ & $\mathrm{X}$ & & & & \\
\hline \multicolumn{7}{|l|}{ Psittacidae } \\
\hline Anodorhynchus hyacinthinus Hyacinthine Macaw ${ }^{\mathrm{VU}}$ (Latham, 1790) & $\mathrm{X}$ & $\mathrm{X}$ & $\mathrm{X}$ & $\mathrm{X}$ & $\mathrm{X}$ & \\
\hline Ara ararauna Blue-and-yellow Macaw (Linnaeus, 1758) & $\mathrm{X}$ & $\mathrm{X}$ & $X$ & $X$ & $X$ & \\
\hline Ara chloropterus Red-and-green Macaw Gray, 1859 & $\mathrm{X}$ & $\mathrm{X}$ & $\mathrm{X}$ & $\mathrm{X}$ & $X$ & \\
\hline Primolius auricollis Yellow-collared Macaw (Cassin, 1853) & $\mathrm{X}$ & $\mathrm{X}$ & $\mathrm{X}$ & $\mathrm{X}$ & $\mathrm{X}$ & \\
\hline
\end{tabular}


APPENDIX 1 (Continued)

\begin{tabular}{|c|c|c|c|c|c|c|}
\hline Rheidae & $\mathrm{RF}$ & SH & FS & $\mathrm{BA}$ & SA & GR \\
\hline Diopsittaca nobilis Red-shoultered Macaw (Linnaeus, 1758) & $\mathrm{X}$ & $\mathrm{X}$ & $\mathrm{X}$ & $\mathrm{X}$ & $\mathrm{X}$ & \\
\hline Thectocercus acuticaudata Blue-crowned Parakeet (Vieillot, 1818) & $\mathrm{X}$ & $\mathrm{X}$ & $\mathrm{X}$ & $\mathrm{X}$ & $\mathrm{X}$ & \\
\hline Psittacara leucophthalmusWhite-eyed Parakeet (Statius Muller, 1776) & & $\mathrm{X}$ & & $\mathrm{X}$ & & \\
\hline Eupsittula aurea Peach-fronted Parakeet (Gmelin, 1788) & $\mathrm{X}$ & $\mathrm{X}$ & $\mathrm{X}$ & $\mathrm{X}$ & $\mathrm{X}$ & \\
\hline Aratinga nenday Nanday Parakeet (Vieillot, 1823) & & $\mathrm{X}$ & $\mathrm{X}$ & $\mathrm{X}$ & $\mathrm{X}$ & \\
\hline Myiopsitta monachus Monk Parakeet (Boddaert, 1783) & & $\mathrm{X}$ & & & & \\
\hline Brotogeris chiriri Canary-winged Parakeet (Vieillot, 1818) & $\mathrm{X}$ & $\mathrm{X}$ & $\mathrm{X}$ & $\mathrm{X}$ & $\mathrm{X}$ & \\
\hline Pionus menstruus Blue-headed $\operatorname{Parrot}^{\mathrm{V}}$ (Linnaeus, 1766) & & $\mathrm{X}$ & $\mathrm{X}$ & & & \\
\hline Pionus maximiliani Scaly-headed Parrot (Kuhl, 1820) & & $\mathrm{X}$ & $\mathrm{X}$ & $\mathrm{X}$ & & \\
\hline Alipiopsitta xanthops Yellow-faced Parrot ${ }^{\mathrm{VU} / \mathrm{V}}$ (Spix, 1824) & & $\mathrm{X}$ & $\mathrm{X}$ & & & \\
\hline Amazona aestiva Blue-fronted Parrot (Linnaeus, 1758) & $\mathrm{X}$ & $\mathrm{X}$ & $\mathrm{X}$ & $\mathrm{X}$ & $\mathrm{X}$ & \\
\hline Amazona amazonica Orange-winged Parrot (Linnaeus, 1766) & $\mathrm{X}$ & $\mathrm{X}$ & $\mathrm{X}$ & & $\mathrm{X}$ & \\
\hline \multicolumn{7}{|l|}{ Cuculidae } \\
\hline Coccyzus melacoryphus Dark-billed Cuckoo ${ }^{\mathrm{M}}$ Vieillot, 1817 & & $\mathrm{X}$ & & & & \\
\hline Micrococcyx cinereus Ash-colored Cuckoo ${ }^{\mathrm{M}}$ Vieillot, 1817 & & $\mathrm{X}$ & & & & \\
\hline Coccyzus americanus Yellow-billed Cuckoo ${ }^{\mathrm{M}}$ (Linnaeus, 1758) & & $\mathrm{X}$ & & & & \\
\hline Piaya cayana Squirrel Cuckoo (Linnaeus, 1766) & $\mathrm{X}$ & $\mathrm{X}$ & $\mathrm{X}$ & $\mathrm{X}$ & $\mathrm{X}$ & \\
\hline Coccycua minuta Little Cuckoo ${ }^{\mathrm{V}}$ (Vieillot, 1817) & $\mathrm{X}$ & & & & & \\
\hline Crotophaga ani Smooth-billed Ani Linnaeus, 1758 & & $\mathrm{X}$ & & $\mathrm{X}$ & $\mathrm{X}$ & $\mathrm{X}$ \\
\hline Crotophaga major Greater ani ${ }^{\mathrm{M}}$ Gmelin, 1788 & $\mathrm{X}$ & & & & & \\
\hline Guira guira ${ }^{\mathrm{b}}$ Guira Cuckoo (Gmelin, 1788) & & $\mathrm{X}$ & & $\mathrm{X}$ & $\mathrm{X}$ & $\mathrm{X}$ \\
\hline Tapera naevia Striped Cuckoo (Linnaeus, 1766) & & $\mathrm{X}$ & $\mathrm{X}$ & & & \\
\hline Dromococcyx pavoninus Pavonine Cuckoo Pelzeln, 1870 & & $\mathrm{X}$ & $\mathrm{X}$ & & & \\
\hline \multicolumn{7}{|l|}{ Tytonidae } \\
\hline Tyto furcataBarn Owl (Scopoli, 1769) & & $\mathrm{X}$ & & & & \\
\hline \multicolumn{7}{|l|}{ Strigidae } \\
\hline Megascops choliba Tropical Screech-Owl (Vieillot, 1817) & & $\mathrm{X}$ & & & & \\
\hline Bubo virginianus Great Horned Owl (Gmelin, 1788) & & $\mathrm{X}$ & & & & \\
\hline Glaucidium brasilianum ${ }^{\text {b }}$ Ferruginoum Pigmy-Owl (Gmelin, 1788) & $\mathrm{X}$ & $\mathrm{X}$ & & & & \\
\hline Athene cunicularia Burrowing Owl (Molina, 1782) & & $\mathrm{X}$ & & & & $\mathrm{X}$ \\
\hline Pulsatrix perspicillata Spectacled Owl (Latham, 1790) & & $\mathrm{X}$ & & & & \\
\hline Strix huhula Black-banded Owl Daudin, 1800 & & $\mathrm{X}$ & & & & \\
\hline \multicolumn{7}{|l|}{ Nyctibiidae } \\
\hline Nyctibius grandis Great potto (Gmelin, 1789) & & $\mathrm{X}$ & & & & $\mathrm{X}$ \\
\hline Nyctibius griseus Grey Potoo (Gmelin, 1789) & & $\mathrm{X}$ & $\mathrm{X}$ & & & $\mathrm{X}$ \\
\hline \multicolumn{7}{|l|}{ Caprimulgidae } \\
\hline Lurocalis semitorquatus Short-Tailed Nighthawk (Gmelin, 1789) & $\mathrm{X}$ & $\mathrm{X}$ & & & & \\
\hline Chordeiles acutipennis Lesser nighthawk (Hermann, 1783) & $\mathrm{X}$ & & & & & \\
\hline Nyctiprogne leucopyga Band-tailed Nighthawk (Spix, 1825) & & $\mathrm{X}$ & & & & \\
\hline Podager nacunda Nacunda Nighthawk (Vieillot, 1817) & & $\mathrm{X}$ & & & & $\mathrm{X}$ \\
\hline Nyctidromus albicollis Pauraque (Gmelin, 1789) & & $\mathrm{X}$ & & & & $\mathrm{X}$ \\
\hline Antrostomus rufus Rufous Nightjar (Boddaert, 1783) & & $\mathrm{X}$ & & & & $\mathrm{X}$ \\
\hline Hydropsalis parvula Little Nightjar (Gould, 1837) & & $\mathrm{X}$ & & & & $\mathrm{X}$ \\
\hline Hydropsalis torquata Scissor-tailed Nightjar (Gmelin, 1789) & & $\mathrm{X}$ & & & & $\mathrm{X}$ \\
\hline \multicolumn{7}{|l|}{ Apodidae } \\
\hline \multicolumn{7}{|l|}{ Chaetura meridionalis Ashy-tailed Swift ${ }^{\mathrm{V}}$ Hellmayr, 1907} \\
\hline Trochilidae & & & & & & \\
\hline
\end{tabular}


APPENDIX 1 (Continued)

\begin{tabular}{|c|c|c|c|c|c|c|}
\hline Rheidae & RF & $\mathrm{SH}$ & FS & $\mathrm{BA}$ & SA & GR \\
\hline Phaethornis pretrei Planalto Hermit (Lesson \& Delattre, 1839) & $\mathrm{X}$ & $\mathrm{X}$ & & & & \\
\hline Eupetomena macrouraSwallow-tailed Hummingbird (Gmelin, 1788) & & $\mathrm{X}$ & & & & \\
\hline Anthracothorax nigricollis Black-throated Mango (Vieillot, 1817) & & $\mathrm{X}$ & & & & \\
\hline Chlorostilbon lucidus Glittering-bellied Emerald (Shaw, 1812) & & $\mathrm{X}$ & & $\mathrm{X}$ & & \\
\hline Thalurania furcata Fork-tailed Woodnymph (Gmelin, 1788) & & $\mathrm{X}$ & & & & \\
\hline Hylocharis chrysura Gilded Hummingbird (Shaw, 1812) & $\mathrm{X}$ & $\mathrm{X}$ & & & & \\
\hline Amazilia versicolor Versicoloured Emerald (Vieillot, 1818) & & $\mathrm{X}$ & & & & \\
\hline Amazilia fimbriata Glittering-throated Emerald (Gmelin, 1788) & & $\mathrm{X}$ & & & & \\
\hline \multicolumn{7}{|l|}{ Trogonidae } \\
\hline Trogon curucui $^{\mathrm{b}}$ Blue-crowned Trogon Linnaeus, 1766 & $\mathrm{X}$ & $\mathrm{X}$ & $\mathrm{X}$ & $\mathrm{X}$ & & \\
\hline \multicolumn{7}{|l|}{ Alcedinidae } \\
\hline Megaceryle torquata Ringed Kingfisher (Linnaeus, 1766) & $\mathrm{X}$ & & & $\mathrm{X}$ & & \\
\hline Chloroceryle amazona ${ }^{\mathrm{b}}$ Amazon Kingfisher (Latham, 1790) & $\mathrm{X}$ & & & $\mathrm{X}$ & & \\
\hline Chloroceryle americana ${ }^{\mathrm{b}}$ Green Kingfisher (Gmelin, 1788) & $\mathrm{X}$ & & & $\mathrm{X}$ & & \\
\hline Chloroceryle ind $a^{\mathrm{b}}$ Green-and-Rufous Kingfisher (Linnaeus, 1766) & $\mathrm{X}$ & & & & & \\
\hline Chloroceryle aenea American Pygmy Kingfisher (Pallas, 1764) & $\mathrm{X}$ & & & & & \\
\hline \multicolumn{7}{|l|}{ Momotidae } \\
\hline Momotus momota Blue-crowned Motmot (Linnaeus, 1766) & $\mathrm{X}$ & & & & & \\
\hline \multicolumn{7}{|l|}{ Galbulidae } \\
\hline Galbula ruficauda $^{\text {b }}$ Rufous-tailed Jacamar Cuvier, 1816 & $\mathrm{X}$ & $\mathrm{X}$ & & & & \\
\hline \multicolumn{7}{|l|}{ Bucconidae } \\
\hline Nystalus maculatus Spot-backed Puffbird (Gmelin, 1788) & & $\mathrm{X}$ & & & & \\
\hline \multicolumn{7}{|l|}{ Ramphastidae } \\
\hline Pteroglossus castanotis Chestnut-eared Araçari Gould, 1834 & & $\mathrm{X}$ & & & & \\
\hline Ramphastos toco Toco Toucan Statius Muller, 1776 & $\mathrm{X}$ & $\mathrm{X}$ & & $\mathrm{X}$ & & \\
\hline \multicolumn{7}{|l|}{ Picidae } \\
\hline Picumnus albosquamatus White-wedged Piculet d'Orbigny, 1840 & $\mathrm{X}$ & $\mathrm{X}$ & $\mathrm{X}$ & & & \\
\hline Colaptes campestris $^{\mathrm{b}}$ Campos Flicker (Vieillot, 1818) & & $\mathrm{X}$ & & $\mathrm{X}$ & $\mathrm{X}$ & $\mathrm{X}$ \\
\hline Colaptes melanochloros Green-barred Woodpecker (Gmelin, 1788) & & $\mathrm{X}$ & $\mathrm{X}$ & & & \\
\hline Piculus chrysochloros Golden-green Woodpecker (Vieillot, 1818) & & $\mathrm{X}$ & $\mathrm{X}$ & & & \\
\hline Celeus flavescens Blond-crested Woodpecker (Gmelin, 1788) & & $\mathrm{X}$ & $\mathrm{X}$ & & & \\
\hline Celeus lugubris Pale-crested Woodpecker (Malherbe, 1851) & $\mathrm{X}$ & $\mathrm{X}$ & $\mathrm{X}$ & & $\mathrm{X}$ & \\
\hline Dryocopus lineatus Lineated Woodpecker (Linnaeus, 1766) & $\mathrm{X}$ & $\mathrm{X}$ & $\mathrm{X}$ & & $\mathrm{X}$ & \\
\hline Melanerpes candidus White Woodpecker (Otto, 1796) & & $\mathrm{X}$ & $\mathrm{X}$ & $\mathrm{X}$ & $\mathrm{X}$ & \\
\hline Melanerpes cactorum White-fronted Woodpecker (d’Orbigny, 1840) & & $\mathrm{X}$ & & & & \\
\hline Veniliornis passerinus Little Woodpecker (Linnaeus, 1766) & $\mathrm{X}$ & $\mathrm{X}$ & $\mathrm{X}$ & & $\mathrm{X}$ & \\
\hline Campephilus melanoleucos Crimson-crested Woodpecker (Gmelin, 1788) & & $\mathrm{X}$ & $\mathrm{X}$ & & & \\
\hline Campephilus leucopogon Cream-backed Woodpecker (Valenciennes, 1826) & & $\mathrm{X}$ & $\mathrm{X}$ & & & \\
\hline Melanerpes flavifrons Yellow-fronted Woodpecker (Vieillot, 1818) & & $\mathrm{X}$ & $\mathrm{X}$ & & & \\
\hline \multicolumn{7}{|l|}{ Thamnophilidae } \\
\hline Taraba major ${ }^{\mathrm{b}}$ Great Antshrike (Vieillot, 1816) & $\mathrm{X}$ & $\mathrm{X}$ & $\mathrm{X}$ & $\mathrm{X}$ & $\mathrm{X}$ & \\
\hline Thamnophilus doliatus ${ }^{\mathrm{b}}$ Barred Antshrike (Linnaeus, 1764) & $\mathrm{X}$ & $\mathrm{X}$ & $\mathrm{X}$ & $\mathrm{X}$ & & \\
\hline Thamnophilus pelzelni Planalto Slaty Antshrike Hellmayr, 1924 & $\mathrm{X}$ & & & & & \\
\hline Thamnophilus caerulescens Variable Antshrike Vieillot, 1816 & $\mathrm{X}$ & & $\mathrm{X}$ & & & \\
\hline Dysithamnus mentalis Plain Antvireo (Temminck, 1823) & $\mathrm{X}$ & & & & & \\
\hline Formicivora rufa ${ }^{\text {b }}$ Rusty-backed Antwren (Wied, 1831) & & $\mathrm{X}$ & & $\mathrm{X}$ & & \\
\hline Cercomacra melanaria ${ }^{\mathrm{b}}$ Mato Grosso Antbird (Ménétriès, 1835) & $\mathrm{X}$ & & & & & \\
\hline
\end{tabular}


Furnariidae

Furnarius rufus ${ }^{\mathrm{b}}$ Rufous Hornero (Gmelin, 1788)

Furnarius leucopus ${ }^{\mathrm{b}}$ Pale-legged Hornero Swainson, 1838

Schoeniophylax phryganophilus Chotoy Spinetail (Vieillot, 1817)

Synallaxis frontalis Sooty-fronted Spinetail Pelzeln, 1859

Synallaxis albescens Pale-breasted Spinetail Temminck, 1823

Synallaxis albilora ${ }^{\mathrm{b}}$ Plain-crowned Spinetail Pelzeln, 1856

Certhiaxis cinnamomeus Yellow-chinned Spinetail (Gmelin, 1788)

Cranioleuca vulpina $^{\text {b }}$ Rusty-backed Spinetail (Pelzeln, 1856)

Phacellodomus rufifrons Plain Thombird (Wied, 1821)

Phacellodomus ruber Greater Thombird (Vieillot, 1817)

Pseudoseisura unirufa ${ }^{\mathrm{b}}$ Grey-crested Cachalote (d'Orbigny \& Lafresnaye, 1838)

Dendrocolaptidae

Sittasomus griseicapillus ${ }^{\mathrm{b}}$ Olivaceus Woodcreeper (Vieillot, 1818)

Xiphocolaptes major Great Rufous Woodcreeper (Vieillot, 1818)

Dendrocolaptes platyrostris ${ }^{\mathrm{b}}$ Planalto Woodcreeper Spix, 1825

Dendroplex picus Straight-billed Woodcreeper (Gmelin, 1788)

Lepidocolaptes angustirostris ${ }^{\mathrm{b}}$ Narrow-billed Woodcreeper (Vieillot, 1818)

Campylorhamphus trochlirostris ${ }^{\mathrm{b}}$ Red-billed Scyhebill (Lichtenstein, 1820)

Tityridae

Xenopsaris albinucha White-naped Xenopsaris (Burmeister, 1869)

Pachyramphus viridis ${ }^{\mathrm{b}}$ Green-backed Becard (Vieillot, 1816)

Pachyramphus polychopterus White-winged Becard (Vieillot, 1818)

Pachyramphus validus Crested Becard (Lichtenstein, 1823)

Tityra cayana Black-tailed Tityra (Linnaeus, 1766)

Tityra inquisitor Black-crowned Tityra (Lichtenstein, 1823)

Rynchocyclidae

Leptopogon amaurocephalus Sepia-capped Flycatcher Tschudi, 1846

Hemitriccus margaritaceiventer ${ }^{\text {b }}$ Pearly-vented Tody-Tyrant (d'Orbigny \& Lafresnaye,1837)

Todirostrum cinereum Common Tody-Flycatcher (Linnaeus, 1766)

Poecilotriccus latirostris ${ }^{\mathrm{b}}$ Rusty-fronted Tody-Flycatcher (Pelzeln, 1868)

Tolmomyias sulphurescens ${ }^{\mathrm{b}}$ Yellow-olive Flycatcher (Spix, 1825)

Tyrannidae

Phyllomyias fasciatus Planalto Tyrannulet (Thunberg, 1822)

Camptostoma obsoletum ${ }^{\mathrm{b}}$ Southern Beardless Tyrannulet (Temminck, 1824)

Phaeomyias murina Mouse-coloured Tyrannulet (Spix, 1825)

Sublegatus modestus Southern Scrub Flycatcher (Wied, 1831)

Suiriri suiriri Chaco Suiriri (Vieillot, 1818)

Myiopagis viridicata ${ }^{\mathrm{b}}$ Greenish Elaenia (Vieillot, 1817)

Elaenia flavogaster Yellow-bellied Elaenia (Thunberg, 1822)

Elaenia parvirostris Small-billed Elaenia Pelzeln, 1868

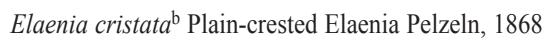

Elaenia chiriquensis Lesser Elaenia Lawrence, 1865

Serpophaga subcristata White-crested Tyrannulet (Vieillot, 1817)

Euscarthmus meloryphus Tawny-crowned Pigmy-Tyrant ${ }^{\mathrm{V}}$ Wied, 1831

Capsiempis flaveola Yellow Tyrannulet (Lichtenstein, 1823)

Myiophobus fasciatus Bran-coloured Flycatcher (Statius Muller, 1776)
X

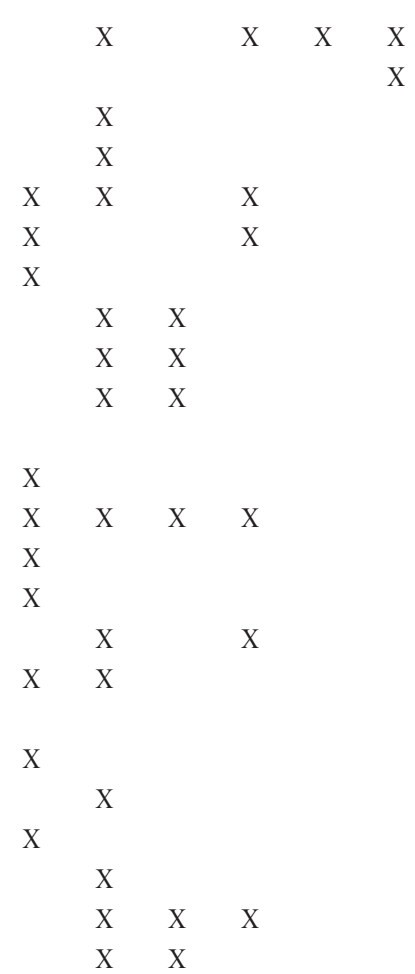

$\mathrm{X}$

$\begin{array}{ccc} & & X \\ & X & X \\ & X & \\ X & & X\end{array}$

X

$\mathrm{X}$

X $\quad$ X

X $\quad X$

$\mathrm{X}$

X

X

X

X

X

X

X

X

X 
APPENDIX 1 (Continued)

\begin{tabular}{|c|c|c|c|c|c|c|}
\hline Rheidae & $\mathrm{RF}$ & $\mathrm{SH}$ & FS & $\mathrm{BA}$ & SA & GR \\
\hline Contopus cinereus Tropical Pewee (Spix, 1825) & & $\mathrm{X}$ & & & & \\
\hline Lathrotriccus euleri ${ }^{\mathrm{b}}$ Euler's Flycatcher (Cabanis, 1868) & $\mathrm{X}$ & & $\mathrm{X}$ & & & \\
\hline Cnemotriccus fuscatus ${ }^{\mathrm{b}}$ Fuscus Flycatcher (Wied, 1831) & & & $\mathrm{X}$ & & & \\
\hline Pyrocephalus rubinus Vermilion Flycatcher (Boddaert, 1783) & & $\mathrm{X}$ & & & & \\
\hline Xolmis cinereus Grey Monjita (Vieillot, 1816) & & $\mathrm{X}$ & & & & $\mathrm{X}$ \\
\hline Xolmis velatus White-rumped Monjita (Lichtenstein, 1823) & & $\mathrm{X}$ & & $\mathrm{X}$ & & $\mathrm{X}$ \\
\hline Fluvicola albiventer Black-backed Water-Tyrant (Spix, 1825) & & $\mathrm{X}$ & & & & \\
\hline Colonia colonus Long-tailed Tyrant (Vieillot, 1818) & & $\mathrm{X}$ & & & & \\
\hline Gubernetes yetapa Streamer-tailed Tyrant (Vieillot, 1818) & & $\mathrm{X}$ & & & & $\mathrm{X}$ \\
\hline Satrapa icterophrys Yellow-browed Tyrant (Vieillot, 1818) & & $\mathrm{X}$ & & & & \\
\hline Machetornis rixosa Cattle Tyrant (Vieillot, 1819) & & $\mathrm{X}$ & & $\mathrm{X}$ & & \\
\hline Casiornis rufus ${ }^{\mathrm{b}}$ Rufous Casiornis (Vieillot, 1816) & & & $\mathrm{X}$ & & & \\
\hline Arundinicola leucocephala White-headed Marsh-Tyrant (Linnaeus, 1764) & $\mathrm{X}$ & & & $\mathrm{X}$ & & \\
\hline Myiarchus ferox ${ }^{\mathrm{b}}$ Short-crested Flycatcher (Gmelin, 1789) & $\mathrm{X}$ & & & $\mathrm{X}$ & & \\
\hline Myiarchus tyrannulus ${ }^{\mathrm{b}}$ Brown-crested Flycatcher (Statius Muller, 1776) & & $\mathrm{X}$ & $\mathrm{X}$ & & & \\
\hline Myiarchus swainsoni Swainson's Flycatcher Cabanis \& Heine, 1859 & & $\mathrm{X}$ & & & & \\
\hline Philohydor lictor Lesser kiskadee (Lichtenstein, 1823) & $\mathrm{X}$ & & & & & \\
\hline Pitangus sulphuratus ${ }^{\mathrm{b}}$ Great Kiskadee (Linnaeus, 1766) & $\mathrm{X}$ & $\mathrm{X}$ & $\mathrm{X}$ & $\mathrm{X}$ & $\mathrm{X}$ & $\mathrm{X}$ \\
\hline Megarynchus pitangua Boat-billed Flycatcher (Linnaeus, 1766) & $\mathrm{X}$ & $\mathrm{X}$ & $\mathrm{X}$ & $\mathrm{X}$ & $\mathrm{X}$ & \\
\hline Myiozetetes cayanensis Rusty-margined Flycatcher (Linnaeus, 1766) & $\mathrm{X}$ & $\mathrm{X}$ & & & & \\
\hline Conopias trivirgatus Three-striped Flycatcher (Wied, 1831) & & $\mathrm{X}$ & & & & \\
\hline Myiodynastes maculatus Streaked Flycatcher (Statius Muller, 1776) & & $\mathrm{X}$ & $\mathrm{X}$ & $\mathrm{X}$ & & \\
\hline Legatus leucophaius Piratic Flycatcher (Vieillot, 1818) & & $\mathrm{X}$ & $\mathrm{X}$ & & & \\
\hline Empidonomus varius Variegated Flycatcher (Vieillot, 1818) & & $\mathrm{X}$ & $\mathrm{X}$ & & & \\
\hline Griseotyrannus aurantioatrocristatus Crowned Slaty-Flycatcher (d'Orbigny \& & & X & X & & & \\
\hline Lafresnaye, 1837) & & & & & & \\
\hline Tyrannus savana Fork-tailed Flycatcher Vieillot, 1808 & & $\mathrm{X}$ & & & & \\
\hline Tyrannus melancholicus Tropical Kingbird Vieillot, 1819 & & $\mathrm{X}$ & & $\mathrm{X}$ & & \\
\hline \multicolumn{7}{|l|}{ Pipridae } \\
\hline Pipra fasciicauda ${ }^{\mathrm{b}}$ Band-tailed Manakin Hellmayr, 1906 & $\mathrm{X}$ & & & & & \\
\hline Antilophia galeata Helmeted Manakin (Lichtenstein, 1823) & $\mathrm{X}$ & & & & & \\
\hline Neopelma pallescens Pale-bellied Tyrant-Manakin (Lafresnaye, 1853) & $\mathrm{X}$ & & & & & \\
\hline \multicolumn{7}{|l|}{ Hirundinidae } \\
\hline \multicolumn{7}{|l|}{ Tachycineta albiventer White-winged Swallow ${ }^{\mathrm{M}}$ (Boddaert, 1783) } \\
\hline \multicolumn{7}{|l|}{ Tachycineta leucorrhoa White-rumped Swallow ${ }^{\mathrm{M}}$ (Vieillot, 1817) } \\
\hline \multicolumn{7}{|l|}{ Progne tapera Brown-chested Martin (Vieillot, 1817) } \\
\hline Progne chalybea Gray-brasted Martin (Gmelin, 1789) & $\mathrm{X}$ & $\mathrm{X}$ & $\mathrm{X}$ & & & \\
\hline Pygochelidon cyanoleuca Blue-and-white Swallow (Vieillot, 1817) & $\mathrm{X}$ & $\mathrm{X}$ & $\mathrm{X}$ & & & \\
\hline \multicolumn{7}{|l|}{ Alopochelidon fucata Tawny-headed Swallow ${ }^{\mathrm{M}}$ (Temminck, 1822) } \\
\hline \multicolumn{7}{|l|}{ Stelgidopteryx ruficollis Southern Rough-winged Swallow (Vieillot, 1817) } \\
\hline \multicolumn{7}{|l|}{ Riparia riparia Bank Swallow ${ }^{\mathrm{M}}$ (Linnaeus, 1758) } \\
\hline \multicolumn{7}{|l|}{ Hirundo rustica Barn Swallow ${ }^{\mathrm{M}}$ Linnaeus, 1758} \\
\hline \multicolumn{7}{|l|}{ Petrochelidon pyrrhonota Cliff Swallow ${ }^{\mathrm{M}}$ (Vieillot, 1817) } \\
\hline \multicolumn{7}{|l|}{ Corvidae } \\
\hline Cyanocorax cyanomelas Purplish Jay (Vieillot, 1818) & $\mathrm{X}$ & $\mathrm{X}$ & $\mathrm{X}$ & $\mathrm{X}$ & $\mathrm{X}$ & \\
\hline Cyanocorax cristatellus Curl-crested Jay (Temminck, 1823) & $\mathrm{X}$ & $\mathrm{X}$ & $\mathrm{X}$ & & & \\
\hline Cyanocorax chrysops Plush-crested Jay (Vieillot, 1818) & $\mathrm{X}$ & $\mathrm{X}$ & $\mathrm{X}$ & $\mathrm{X}$ & $\mathrm{X}$ & \\
\hline
\end{tabular}


Troglodytidae

Campylorhynchus turdinus ${ }^{\mathrm{b}}$ Thrush-like Wren (Wied, 1831)

Cantorchilus leucotis ${ }^{\mathrm{b}}$ Buff-breasted Wren // (Lafresnaye, 1845)

Troglodytes musculus House Wren Naumann, 1823

Donacobiidae

Donacobius atricapilla Black-capped Donacobius (Linnaeus, 1766)

Polioptilidae

Polioptila dumicola Masked Gnatcatcher (Vieillot, 1817)

Turdidae

Turdus rufiventris ${ }^{\mathrm{b}}$ Rufous-bellied Thrush Vieillot, 1818

Turdus leucomelas Pale-breasted Thrush Vieillot, 1818

Turdus amaurochalinus $^{\mathrm{b}}$ Creamy-bellied Thrush Cabanis, 1850

Mimidae

Mimus saturninus ${ }^{\mathrm{b}}$ Chalk-browed Mockingbird (Lichtenstein, 1823)

Motacillidae

Anthus lutescens Yellowish Pipit Pucheran, 1855

Vireonidae

Cyclarhis gujanensis Rufous-browned Peppershirke (Gmelin, 1789)

Vireo chivi $^{\mathrm{b}}$ Red-eyed Vireo (Linnaeus, 1766)

Icteridae

Psarocolius decumanus Crested Oropendola (Pallas, 1769)

Cacicus cela Yellow-rumped Cacique (Linnaeus, 1758)

Cacicus chrysopterus Golden-winged Cacique (Vigors, 1825)

Procacicus solitarius Solitary Cacique (Vieillot, 1816)

Icterus cayanensis Epaulet Oriole (Linnaeus, 1766)

Icterus croconotus Orange-backedTroupial (Wagler, 1829)

Agelasticus cyanopus Unicolored Blackbird (Vieillot, 1819)

Chrysomus ruficapillus Chestnut-capped Blackbird (Vieillot, 1819)

Sturnella superciliaris White-browed Blackbird (Bonaparte, 1850)

Amblyramphus holosericeus Scarlet-headed Blackbird (Scopoli, 1786)

Gnorimopsar chopi Chopi Blackbird (Vieillot, 1819)

Pseudoleistes guirahuro Yellow-rumped Marshbird (Vieillot, 1819)

Agelaioides badius Bay-winged Cowbird (Vieillot, 1819)

Molothrus bonariensis Shiny Cowbird (Gmelin, 1789)

Molothrus oryzivorus Giant Cowbird (Gmelin, 1788)

Parulidae

Setophaga pitiayumi ${ }^{\mathrm{b}}$ Tropical Parula (Vieillot, 1817)

Geothlypis aequinoctialis Marked Yellowthroat (Gmelin, 1789)

Myiothlypis flaveola ${ }^{\mathrm{b}}$ Flavescent Warbler Baird, 1865

Basileuterus culicivorus White-bellied Warbler Bonaparte, 1830

Coerebidae

Coereba flaveola Bananaquit (Linnaeus, 1758)

Thraupidae

Schistochlamys melanopis Black-faced Tanager (Latham, 1790)

Neothraupis fasciata White-banded Tanager (Lichtenstein, 1823)

Nemosia pileata Hooded Tanager (Boddaert, 1783)

Eucometis penicilata $^{\mathrm{b}}$ Gray-headed Tanager (Spix, 1825)

$\begin{array}{lllll}X & X & X & X \\ & X & & \\ & X & & \end{array}$

X

$\mathrm{X}$

$\begin{array}{lllll}\text { X } & \text { X } & \text { X } & \text { X } & \text { X } \\ \text { X } & \text { X } & \text { X } & \text { X } & \text { X } \\ \text { X } & \text { X } & \text { X } & \text { X } & \text { X }\end{array}$

$\mathrm{X}$

$\mathrm{X}$

X

$\begin{array}{llllll}X & X & X & X & & \\ X & X & X & & & \\ & & & & & \\ X & X & X & X & X & \\ X & X & X & & & \\ X & X & X & X & X & \\ X & X & X & & & \\ X & X & X & X & X & \\ & & & X & X & X \\ & & & & & X \\ & & & X & X & X \\ & & & X & X & X \\ & X & X & & & \\ & X & & & & X \\ X & & & & \\ X & & & & \\ X & & & & \end{array}$

$\begin{array}{ll} & X \\ & X \\ X & \\ X & \end{array}$

$\mathrm{X}$

$\mathrm{X}$

$\mathrm{X}$

$\mathrm{X}$

X 


\section{APPENDIX 1 (Continued)}

\begin{tabular}{|c|c|c|c|c|c|c|}
\hline Rheidae & $\mathrm{RF}$ & $\mathrm{SH}$ & FS & $\mathrm{BA}$ & SA & GR \\
\hline Tachyphonus rufus White-lined Tanager (Boddaert, 1783) & $\mathrm{X}$ & & & & & \\
\hline Ramphocelus carbo ${ }^{\mathrm{b}}$ Silver-beaked Tanager (Pallas, 1764) & $\mathrm{X}$ & $\mathrm{X}$ & $\mathrm{X}$ & $\mathrm{X}$ & $\mathrm{X}$ & \\
\hline Tangara sayaca ${ }^{\mathrm{b}}$ Sayaca Tanager (Linnaeus, 1766) & $\mathrm{X}$ & $\mathrm{X}$ & $\mathrm{X}$ & $\mathrm{X}$ & $\mathrm{X}$ & \\
\hline Tangara palmarum ${ }^{\mathrm{b}}$ Palm Tanager (Wied, 1823) & & $\mathrm{X}$ & & $\mathrm{X}$ & $\mathrm{X}$ & \\
\hline Pipraeidea melanonota Fawn-breasted Tanager (Vieillot, 1819) & & $\mathrm{X}$ & & & & \\
\hline Tangara cayana Burnished-buff Tanager (Linnaeus, 1766) & & $\mathrm{X}$ & & & & \\
\hline Dacnis cayanaBlue Dacnis (Linnaeus, 1766) & & $\mathrm{X}$ & & & & \\
\hline Conirostrum speciosum Chestnut-vented Conebill (Temminck, 1824) & $\mathrm{X}$ & & & & & \\
\hline Tersina viridisSwallon Tanager (Illiger, 1811) & $\mathrm{X}$ & & & & & \\
\hline Saltator coerulescens Greyish Saltator Vieillot, 1817 & & & & & & $\mathrm{X}$ \\
\hline Coryphospingus cucullatus ${ }^{\mathrm{b}}$ Red-crested Finch (Statius Muller, 1776) & $\mathrm{X}$ & $\mathrm{X}$ & & & & $\mathrm{X}$ \\
\hline Paroaria coronata ${ }^{\text {Red-crested Cardinal (Miller, 1776) }}$ & $\mathrm{X}$ & $\mathrm{X}$ & & & & \\
\hline Paroaria capitata $^{\mathrm{b}}$ Yellow-billed Cardinal (d’Orbigny \& Lafresnaye, 1837) & & $\mathrm{X}$ & & $\mathrm{X}$ & & $\mathrm{X}$ \\
\hline Saltator maximus Buff-throated Saltator (Statius Muller, 1776) & $\mathrm{X}$ & & & & & \\
\hline Saltator similisGreen-winged Saltator Vieillot, 1817 & $\mathrm{X}$ & $\mathrm{X}$ & & & & \\
\hline \multicolumn{7}{|l|}{ Emberizidae } \\
\hline Zonotrichia capensis Rufous-collared Sparrow (Statius Muller, 1776) & & & & & & $\mathrm{X}$ \\
\hline Ammodramus humeralis Grassland Sparrow (Bosc, 1792) & & & & & & $\mathrm{X}$ \\
\hline Sicalis flaveola ${ }^{\mathrm{b}}$ Saffron Finch (Linnaeus, 1766) & & & & & & $\mathrm{X}$ \\
\hline Emberizoides herbicola Wedge-tailed Grass-finch (Vieillot, 1817) & & & & & & $\mathrm{X}$ \\
\hline Volatinia jacarina Blue-black Grassquit (Linnaeus, 1766) & & & & & & $X$ \\
\hline Sporophila plumbea Plumbeus Seedeater (Wied, 1830) & & & & & & $\mathrm{X}$ \\
\hline Sporophila collaris ${ }^{\mathrm{b}}$ Rusty-collared Seedeater (Boddaert, 1783) & & & & $\mathrm{X}$ & & $\mathrm{X}$ \\
\hline Sporophila lineola Lined Seedeater (Linnaeus, 1758) & & & & & & $\mathrm{X}$ \\
\hline Sporophila nigricollis Yellow-bellied Seedeater (Vieillot, 1823) & & & & & & $\mathrm{X}$ \\
\hline Sporophila caerulescens $s^{\mathrm{b}}$ Double-collared Seedeater (Vieillot, 1823) & & & & $\mathrm{X}$ & & $\mathrm{X}$ \\
\hline Sporophila leucoptera White-bellied Seedeater (Vieillot, 1817) & & & & & & $\mathrm{X}$ \\
\hline Sporophila hypoxantha Tawny-bellied Seedeater ${ }^{\mathrm{V}}$ Cabanis, 1851 & & & & & & $\mathrm{X}$ \\
\hline Sporophila ruficollis Dark-throated Seedeater ${ }^{\mathrm{V}}$ Cabanis, 1851 & & & & & & $\mathrm{X}$ \\
\hline Sporophila angolensis Lesser Seed-Finch (Linnaeus, 1766) & & & & $\mathrm{X}$ & & $\mathrm{X}$ \\
\hline Arremon flavirostris Saffron-billed Sparrow Swainson, 1838 & $\mathrm{X}$ & & & & & \\
\hline \multicolumn{7}{|l|}{ Cardinalidae } \\
\hline Pheucticus aureoventris Black-backed Grosbeak ${ }^{\mathrm{V}}$ (d'Orbigny \& Lafresnaye, 1837) & & $\mathrm{X}$ & & & & $\mathrm{X}$ \\
\hline \multicolumn{7}{|l|}{ Piranga flava Hepatic Tanager (Vieillot, 1822) } \\
\hline \multicolumn{7}{|l|}{ Fringillidae } \\
\hline Euphonia chlorotica Purple-throated Euphonia (Linnaeus, 1766) & & $X$ & $\mathrm{X}$ & & & \\
\hline
\end{tabular}

Occasional contacts (V), migrant species (M), vulnerable (VU), or Rare (RA) species, b - banded birds. RI, river; RF, riparian forest; $\mathrm{SH}$, savannah; FS, forested savannah; BA, bays; SA, salines and GR, grasslands. 
APPENDIX 2

Number of contacts for the most abundant species (>100 individuals) in the Fazenda Rio Negro between 2001 and 2004

\begin{tabular}{|c|c|c|c|c|c|c|}
\hline Species & English common name & 2001 & 2002 & 2003 & 2004 & Totals \\
\hline Himantopus melanurus & Black-necked stilt & 1098 & 1490 & 1077 & 673 & 4338 \\
\hline Ardea alba & Great egret & 1319 & 591 & 119 & 581 & 2610 \\
\hline Dendrocygna viduata & White-faced whistling duck & 369 & 644 & 198 & 496 & 1707 \\
\hline Ortalis canicollis & Chaco chacalaca & 546 & 479 & 338 & 297 & 1660 \\
\hline Thectocercus acuticaudata & Blue-crowned parakeet & 157 & 874 & 132 & 211 & 1374 \\
\hline Egretta thula & Snowy egret & 334 & 440 & 62 & 253 & 1089 \\
\hline Brotogeris chiriri & Canary-winged parakeet & 347 & 400 & 155 & 150 & 1052 \\
\hline Amazona aestiva & Blue-fronted parrot & 322 & 434 & 152 & 110 & 1018 \\
\hline Phaetusa simplex & Large-billed tern & 285 & 154 & 237 & 252 & 928 \\
\hline Nannopterum brasilianus & Brazilian cormorant & 175 & 640 & 29 & 2 & 846 \\
\hline Dendrocygna autumnalis & Black-bellied whistling duck & 309 & 240 & 56 & 127 & 732 \\
\hline Aburria cumanensis & Blue-throated piping guan & 202 & 218 & 131 & 149 & 700 \\
\hline Leptotila verreauxi & White-tipped dove & 195 & 197 & 207 & 97 & 696 \\
\hline Guira guira & Guira cuckoo & 254 & 208 & 122 & 106 & 690 \\
\hline Ramphocelus carbo & Silver-beaked tanager & 168 & 223 & 106 & 189 & 686 \\
\hline Jacana jacana & Jacana & 130 & 143 & 105 & 286 & 664 \\
\hline Megaceryle torquata & Ringed kingfisher & 183 & 296 & 157 & 26 & 662 \\
\hline Patagioenas picazuro & Picazuro pigeon & 281 & 195 & 57 & 122 & 655 \\
\hline Tachybabtus dominicus & Least grebe & 3 & 554 & 39 & 1 & 597 \\
\hline Crax fasciolata & Bare-faced currasow & 164 & 171 & 153 & 86 & 574 \\
\hline Phimosus infuscatus & Bare-faced ibis & 248 & 169 & 36 & 114 & 567 \\
\hline Crotophaga major & Greater ani & 170 & 147 & 233 & 16 & 566 \\
\hline Cantorchilus leucotis & Buff-necked wren & 198 & 164 & 109 & 95 & 566 \\
\hline Cyanocorax cyanomelas & Purplish jay & 162 & 213 & 91 & 98 & 564 \\
\hline Pitangus sulphuratus & Great kiskadee & 176 & 201 & 68 & 117 & 562 \\
\hline Vanellus chilensis & Southern lapwing & 261 & 133 & 71 & 85 & 550 \\
\hline Rynchops niger & Black skimmer & 164 & 99 & 53 & 196 & 512 \\
\hline Crypturellus undulatus & Undulated tinamous & 205 & 93 & 116 & 95 & 509 \\
\hline Anhinga anhinga & Anhinga & 97 & 252 & 85 & 69 & 503 \\
\hline Tringa melanoleuca & Greater yellowlegs & 89 & 376 & 35 & 1 & 501 \\
\hline Chloroceryle amazona & Amazon kingfisher & 124 & 220 & 134 & 23 & 501 \\
\hline Paroaria capitata & Yellow-billed cardinal & 140 & 204 & 71 & 81 & 496 \\
\hline Vanellus cayanus & Pied plover & 144 & 85 & 118 & 78 & 425 \\
\hline Ardea cocoi & White-faced heron & 47 & 209 & 111 & 50 & 417 \\
\hline Butorides striatus & Striated heron & 98 & 163 & 79 & 41 & 381 \\
\hline Crotophaga ani & Smooth-billed ani & 87 & 135 & 50 & 95 & 367 \\
\hline Stelgidopteryx ruficollis & Southern rough-winged swallow & 118 & 94 & 144 & 1 & 357 \\
\hline Platalea ajaja & Roseate spoonbill & 269 & 51 & 8 & 2 & 330 \\
\hline Furnarius leucopus & Pale-legged hornero & 66 & 57 & 89 & 101 & 313 \\
\hline Amazonetta brasiliensis & Brazilian teal & 104 & 57 & 44 & 78 & 283 \\
\hline Tringa flavipes & Lesser yellowlegs & 135 & 3 & 123 & 1 & 262 \\
\hline Primolius auricollis & Yellow-collared macaw & 23 & 150 & 25 & 60 & 258 \\
\hline Psittacara leucophthalmus & White-eyed parakeet & 148 & 30 & 17 & 51 & 246 \\
\hline Gnorimopsar chopi & Chopi blackbird & 99 & 74 & 59 & 5 & 237 \\
\hline Coragyps atratus & Black vulture & 59 & 111 & 45 & 18 & 233 \\
\hline Psarocolius decumanus & Crested oropendula & 93 & 103 & 26 & 2 & 224 \\
\hline
\end{tabular}


APPENDIX 2 (Continued)

\begin{tabular}{|c|c|c|c|c|c|c|}
\hline Species & English common name & 2001 & 2002 & 2003 & 2004 & Totals \\
\hline Procacicus solitarius & Solitary cacique & 71 & 75 & 31 & 41 & 218 \\
\hline Paroaria coronata & Red-crested cardinal & 84 & 11 & 41 & 74 & 210 \\
\hline Eupsittula aurea & Peach-fronted parakeet & 18 & 130 & 7 & 53 & 208 \\
\hline Cercomacra melanaria & Mato Grosso antbird & 49 & 65 & 64 & 27 & 205 \\
\hline Furnarius rufus & Rufous hornero & 101 & 56 & 34 & 6 & 197 \\
\hline Chloroceryle americana & Green kingfisher & 65 & 45 & 60 & 23 & 193 \\
\hline Philohydor lictor & Lesser kiskadee & 118 & 33 & 39 & 2 & 192 \\
\hline Ara chloroptera & Red-and-green macaw & 47 & 40 & 46 & 57 & 190 \\
\hline Ramphastos toco & Toco toucan & 71 & 75 & 40 & 1 & 187 \\
\hline Patagioenas cayennensis & Pale-vented pigeon & 74 & 29 & 57 & 19 & 179 \\
\hline Eucometis penicilata & Grey-headed tanager & 138 & 2 & 30 & 7 & 177 \\
\hline Taraba major & Great antshrike & 41 & 86 & 44 & 1 & 172 \\
\hline Aramides cajaneus & Grey-necked wood-rail & 39 & 57 & 12 & 55 & 163 \\
\hline Thamnophilus doliatus & Barred antshrike & 83 & 49 & 27 & 1 & 160 \\
\hline Cyanocorax chrysops & Plush-crested jay & 37 & 88 & 15 & 16 & 156 \\
\hline Cairina moschata & Moscovy duck & 26 & 70 & 18 & 39 & 153 \\
\hline Mesembrinibis cayennensis & Green ibis & 13 & 78 & 55 & 3 & 149 \\
\hline Campylorhynchus turdinus & Thrus-like wren & 74 & 8 & 24 & 37 & 143 \\
\hline Syrigma sibilatrix & Whistling heron & 61 & 45 & 29 & 1 & 136 \\
\hline Tigrisoma lineatum & Rufescent tiger heron & 30 & 51 & 53 & 1 & 135 \\
\hline Saltator coerulescens & Greyish saltator & 35 & 51 & 43 & 1 & 130 \\
\hline Galbula ruficauda & Rufous-tailed jacamar & 33 & 51 & 33 & 5 & 122 \\
\hline Cyclarhis gujanensis & Rufous-browed peppershrike & 1 & 62 & 44 & 14 & 121 \\
\hline Myiarchus tyrannulus & Brown-crested flycatcher & 28 & 56 & 32 & 2 & 118 \\
\hline Diopsittaca nobilis & Red-shouldered macaw & 58 & 54 & 5 & 0 & 117 \\
\hline Theristicus caudatus & Buff-necked ibis & 62 & 35 & 18 & 1 & 116 \\
\hline Synallaxis albilora & White-lored spinetail & 6 & 66 & 41 & 1 & 114 \\
\hline Arantiga nenday & Nanday parakeet & 23 & 52 & 37 & 2 & 114 \\
\hline Trogon ситисui & Blue-crowned trogon & 23 & 44 & 45 & 1 & 113 \\
\hline
\end{tabular}

